\title{
Do Rising Top Incomes Lift All Boats?
}

\section{Citation}

Andrews, Daniel, Christopher Jencks, and Andrew Leigh. 2009. Do Rising Top Incomes Lift All Boats? HKS Faculty Research Working Paper Series RWP09-018, John F. Kennedy School of Government, Harvard University.

\section{Published Version}

http://web.hks.harvard.edu/publications/workingpapers/citation.aspx?Publd=6695

\section{Permanent link}

http://nrs.harvard.edu/urn-3:HUL.InstRepos:4415903

\section{Terms of Use}

This article was downloaded from Harvard University's DASH repository, and is made available under the terms and conditions applicable to Other Posted Material, as set forth at http:// nrs.harvard.edu/urn-3:HUL.InstRepos:dash.current.terms-of-use\#LAA

\section{Share Your Story}

The Harvard community has made this article openly available.

Please share how this access benefits you. Submit a story.

Accessibility 


\title{
MARVARD Kennedy School JOHN F. KENNEDY SCHOOL OF GOVERNMENT
}

\author{
Faculty Research Working Papers Series
}

Do Rising Top Incomes Lift All Boats?

\author{
Dan Andrews \\ John F. Kennedy School of Government - Harvard University \\ Christopher Jencks \\ John F. Kennedy School of Government - Harvard University \\ Andrew Leigh \\ Research School of Social Sciences, Australian National University
}

June 2009

RWP09-018

The views expressed in the HKS Faculty Research Working Paper Series are those of the author(s) and do not necessarily reflect those of the John F. Kennedy School of Government or of Harvard University. Faculty Research Working Papers have not undergone formal review and approval. Such papers are included in this series to elicit feedback and to encourage debate on important public policy challenges. Copyright belongs to the author(s). Papers may be downloaded for personal use only. 


\title{
Do Rising Top Incomes Lift All Boats?*
}

\author{
Dan Andrews \\ Graduate student \\ Kennedy School of Government \\ Harvard University \\ dan andrews@,ksg07.harvard.edu \\ Christopher Jencks \\ Kennedy School of Government \\ Harvard University \\ christopher_jencks@harvard.edu \\ Andrew Leigh \\ Research School of Social Sciences \\ Australian National University \\ andrew.leigh@anu.edu.au
}

This version: 15 June 2009

* We are grateful to Tony Atkinson, Dani Rodrik, Sarah Voitchovsky, Daniel Waldenström, and seminar participants at the Australian National University, the Research Institute of Industrial Economics, and the Reserve Bank of Australia for valuable feedback on earlier drafts. 


\title{
Do Rising Top Incomes Lift All Boats?
}

\begin{abstract}
Pooling data for 1905 to 2000 , we find no systematic relationship between top income shares and economic growth in a panel of 12 developed nations observed for between 22 and 85 years. After 1960, however, a one percentage point rise in the top decile's income share is associated with a statistically significant 0.12 point rise in GDP growth during the following year. This relationship is not driven by changes in either educational attainment or top tax rates. If the increase in inequality is permanent, the increase in growth appears to be permanent, but it takes 13 years for the cumulative positive effect of faster growth on the mean income of the bottom nine deciles to offset the negative effect of reducing their share of total income.
\end{abstract}

Keywords: inequality, growth, income distribution, national income JEL Codes: D31, N10, O57 


\section{Introduction}

Research on the relationship between economic inequality and growth expanded rapidly during the 1990s. Initially, several studies suggested that inequality was bad for subsequent growth, but these studies were based on comparisons between countries with different initial levels of inequality, not comparisons between changes in inequality and changes in subsequent growth within the same country. As a result, skeptics found it easy to argue that the results might be due to omitted variable bias. The release of Deininger and Squire's (1996) data set allowed investigators to estimate changes in income inequality within a large number of countries. ${ }^{1}$ This possibility led to a series of papers estimating the effect of changes in inequality on changes in GDP. These papers (notably Forbes 2000) generally found that increases in inequality were good for growth.

Yet even when Deininger and Squire's measures of inequality came from the same country, they were not always comparable to one another. Inequality measures in the Deininger-Squire dataset differ according to whether they are based on income or expenditure, whether they include or exclude taxes, and whether they are based on families or households. Consequently, an influential review by Atkinson and Brandolini (2001) concluded that:

"there is no real alternative to seeking data-sets where the observations are as fully consistent as possible; at the same time, the choice of definition on which to standardize may affect the conclusions drawn ... we are not convinced that at present it is possible to use secondary datasets safely without some knowledge of the underlying sources, and we caution strongly against mechanical use of such data-sets." 
That observation suggests that new data on trends in inequality would be valuable for assessing the impact of inequality on growth. ${ }^{2}$ This paper uses new data derived from tax reports.

The use of tax data to estimate income inequality has a long history (eg. Bowley 1914; Kuznets 1953). Here, we draw on a series of recent papers that have combined tax data with external population and income control totals to estimate the changing share of income going to families and individuals above the 90th percentile of the distribution. We use two such measures: the shares of personal income going to the richest 10 per cent and the richest 1 per cent of the population. These measures are attractive because increases in income inequality since 1980 have been driven primarily by increases in top income shares, making their effect of particular policy interest, and tax data are also the most reliable source of information about top income shares. In addition, tax data are more likely than the diverse surveys that Deininger and Squire collated to employ a consistent methodology from one year to the next. Consequently, these tax data potentially provide a more reliable gauge of changes in inequality than the estimates sourced from the Deininger-Squire database (see Section II). Finally, tax data are usually available on an annual basis, and a number of countries now have such data going back to the first quarter of the twentieth century.

Despite all these advantages, our tax data also have important limitations. In particular, they do not provide information on inequality within the bottom 90 per cent of the distribution. Furthermore, there is some evidence that changes in top income shares do not have the same effect on growth as changes further down in the distribution (Voitchovsky, 2005). 
One central aim of this paper is to re-examine the relationship between inequality - as proxied by the top incomes data - and growth. ${ }^{3}$ Like Forbes (2000), we utilize panel estimation techniques, and like Forbes we find evidence that since 1960 a rise in inequality has been associated with a modest short-term rise in the growth rate. Our second aim is to take advantage of annual data on inequality to calibrate the magnitude and persistence of these positive effects more precisely. Finally, we use these results to estimate how long it is likely to take for the positive effects of higher inequality on growth to offset the negative effects of higher inequality on the share of personal income going to those in the bottom 90 per cent of the distribution.

The paper is structured as follows. Section II briefly discusses the existing literature. Section III describes our data, while Section IV outlines our strategy for estimating the effect of income inequality - measured by the income share of the top ten per cent or top one per cent. Section V presents our basic results, and Section VI provides several robustness checks. Section VII discusses the distributional implications of our findings. We conclude by summarizing our results.

\section{Theory and Existing Evidence}

In principle, top income shares could affect growth in a variety of ways. ${ }^{4}$ If the rich have an unusually high marginal propensity to save, increases in top income shares should increase national savings. Higher savings should, in turn, reduce the price of capital and raise investment, at least in economies that are not fully open to external capital flows. Inequality could also be positively related to growth if set-up costs for investment are large relative to median income, since concentration of asset ownership would then make big investments easier. In addition, if top income shares rise because 
returns to human capital are rising, both current and future workers have more incentive to invest in their human capital, which should eventually lower the cost of human capital and raise the growth rate. Within workplaces, tournament theory suggests that more wage dispersion will lead to higher productivity. ${ }^{5}$ And to the extent that greater returns to entrepreneurship or higher-powered managerial incentives make businesspeople work harder, unequal societies may grow more rapidly.

However, increases in top income shares could also have political consequences that reduce future growth. Larger top income shares make the median voter more likely to gain from redistribution, at least in the short run. If increases in top income shares lead to taxes or transfer payments that distort economic decisions regarding investment or labor supply, investment in both physical and human capital may fall, lowering growth (Barro 2000). The rich may also take actions to prevent redistribution, such as lobbying or buying key votes in legislatures, that slow economic growth. Other channels through which inequality might affect growth - including credit constraints, crime, and corruption - are more relevant to developing countries or to inequality within the bottom 90 per cent of the distribution. ${ }^{6}$ Finally, even if increases in top income shares do not affect growth, there may appear to be a causal link between the two if the same policies that increase growth also increase inequality. Low taxes on either capital gains or income from assets may encourage investment, for example, which may raise both the growth rate and the share of income going to the rich. We address this possibility in our empirical analysis.

Because the sign of inequality's effect on growth is theoretically ambiguous, the issue has inspired a large empirical literature, most of which has focused on the relationship between growth and broad measures of inequality, such as the Gini 
coefficient. The early literature (notably, Alesina and Rodrik 1994, Persson and Tabellini 1994, and Perotti 1996) regressed economic growth over some period (1960-1985 in Alesina and Rodrik) on the initial level of inequality (circa 1960), and found a negative relationship between inequality and growth. However, these studies were obviously susceptible to omitted variable bias, the direction of which was uncertain. ${ }^{7}$ In addition, they did not provide direct evidence on how a change in inequality within a given country affected its future growth (Forbes 2000). By contrast, panel data have allowed recent investigators to see whether changes in inequality within a given country are followed by changes in its growth rate. Using this approach, Forbes (2000) found that an increase in income inequality had a significant positive effect on a country's economic growth over the next five years.

There are at least two possible explanations for the difference between Forbes's findings and earlier studies. One possibility is that the earlier studies failed to control important growth-retarding characteristics of countries with high initial levels of inequality, and that including country fixed effects eliminated this source of bias, allowing Forbes to capture the positive effects of inequality per se. Forbes, however, suggests a second possible explanation, namely that the long-term effects of inequality differ from the short-term effects. Her estimates imply that when the level of inequality is above a country's long-term average, the country grows unusually rapidly over the next few years. The negative relationship found by both Alesina and Rodrik (1994) and Persson and Tabellini (1994) may, in contrast, capture the longer run effect of inequality on growth. If high levels of inequality lower long-term growth by preventing low-income 
parents from investing enough time and money in their children's health and education, for example, this effect could take a generation to influence labor productivity.

If the short-term effects of inequality on growth are positive while the long-term effects are negative, the effect of inequality should decline as the lag between the inequality measure and the growth measure increases. At some point the net effect should be zero, after which it should become negative, at least for a while. The literature is broadly consistent with this hypothesis. When the Gini coefficient is measured on a scale that runs from 0 to 1 , its standard deviation is about 0.1 in the samples used by both Barro (2000) and Forbes (2000). Forbes estimates the effect of inequality on growth 1 to 5 years later, but uses a 5 year lag where possible, so the average lag between the midpoint of the year in which inequality is measured and the midpoint of the growth window is between 3 and 5 years. Barro estimates the effect of inequality on growth 5 to 15 years later, so his lags average 10 years. Forbes finds that a one standard deviation increase in a country's Gini coefficient is followed by a 1.3 per cent increase in its average annual growth, while Barro finds that the same increase in inequality is followed by an 0.5 per cent increase in rich countries' growth and an 0.5 per cent reduction in poor countries' growth. ${ }^{8}$ In Alesina and Rodrik (1994) the lag averages 12.5 years and the overall association is negative. $^{9}$

Most previous literature uses broad measures of inequality like the Gini coefficient that do not distinguish between inequality in the top and bottom parts of the distribution. When Voitchovsky (2005) uses the Luxembourg Income Study (LIS) to separate the effects of changes in inequality above and below the median, she finds that increased inequality in the top half of the income distribution is positively associated with 
subsequent growth while increased inequality in the bottom half of the distribution is negatively associated with subsequent growth. Her estimates use GMM rather than country fixed effects, but they underscore the fact that measuring only inequality between those above and below the $90^{\text {th }}$ percentile may miss important effects of inequality within the bottom nine deciles. However, Barro (2000) finds that his results are qualitatively similar when he replaces the Gini coefficient with the income share of the top quintile.

The empirical literature has not yet thrown much light on the mechanisms that link inequality to growth. Barro (2000) concluded that the channel through which higher inequality fostered growth in rich countries was unlikely to involve investment, since the investment ratio was almost unrelated to inequality. And while Barro did not have data on top income shares, Leigh and Posso (2009) found no systematic relationship between top income shares and savings using data for roughly the same countries and years covered in this paper.

Banerjee and Duflo (2003) question the use of linear models to estimate the effects of changes in inequality on growth. They argue that growth is an inverted Ushaped function of changes in inequality, and that any change in inequality, either positive or negative, lowers growth for the next few years. We test this hypothesis in Section VI and find that it does not hold for top income shares in rich countries.

Since our sample includes only industrialized economies and does not measure inequality within the bottom part of the distribution, past literature suggests that we should find a positive short-term relationship between inequality and growth but that the effect of inequality in any given period should decline over time and perhaps even turn negative. Of course, these expectations assume that the effects of top income shares are 
like the effects of the broader inequality measures, notably the Gini coefficient, used in the earlier literature. That assumption is especially problematic with regard to negative long-term effects of inequality on growth, since negative effects are likely to reflect reductions in the share of total income going to the bottom deciles, which is imperfectly correlated with the share going to the top decile.

One final limitation of past work on inequality and growth deserves attention, because it recurs in this paper. Changes in inequality are seldom attributable to exogenous shocks over which countries have no control. Even when inequality is "caused" by an exogenous shock, such as skill-biased technological change, the observed effect is likely to vary depending upon a country's political and economic institutions and - more proximately - on the political preferences of the governing party. When Sweden allowed economic inequality to rise in the 1990s, it was responding in part to an economic crisis that some Swedes attributed to excessive egalitarianism in the 1980s. One could make a similar argument with regard to the increases in inequality in the United Kingdom during the Thatcher years and the United States during the Reagan era.

It might be possible to address the potential endogeneity of changes in economic inequality by using instrumental variables to estimate the impact of inequality per se on growth. However, the problem with this approach is that it is difficult to identify an instrument that would satisfy the exclusion restriction (ie. the instrument must affect growth only through its impact on inequality). Instead, both we and other researchers deal with the problem by introducing a lag between changes in inequality and changes in growth. This strategy works if the factors that alter inequality in year $y$ have no lagged effects on growth in later years, which seems unlikely. If the changes that drive up 
inequality in year $y$ persist, leading to a sustained increase in inequality, there will be no simple way of separating the impact of inequality on subsequent growth from the effect of the drivers of inequality on subsequent growth. Rather than interpreting the estimated effect of a change in economic inequality as the effect of inequality per se, readers should therefore treat such estimates as potentially including some lagged effects of the institutions, policies, and circumstances that cause inequality to change at different rates and times in different countries. If that is the case, then as Lindert (2004) has forcefully argued, the effect of changes in economic inequality will depend on the particular policies that countries adopt to limit it. We do not address that possibility here.

\section{Top Income Shares}

Our estimates of top income shares are drawn from a series of top incomes papers (Alvaredo and Saez 2006; Atkinson 2007; Atkinson and Leigh 2005; Atkinson and Leigh 2007a; Dell 2007; Dell, Piketty and Saez 2007; Nolan 2007; Piketty 2007; Piketty and Saez 2006b; Roine and Waldenström 2008; Saez and Veall 2005; Salverda and Atkinson 2007), many of which have been published or republished in the volumes edited by Atkinson and Piketty $(2007,2009)$. We use two measures - the share of pretax income received by the richest 10 per cent and the richest 1 per cent of the population. Leigh (2007) makes some minor adjustments to the published series in order to create a more harmonized series for 12 rich countries. ${ }^{10}$

Our data provides estimates for an average of 62 years per country in the case of the top 10 per cent and 68 years per country in the case of the top 1 per cent (Table A1 shows the exact years for the top 10 per cent share). These estimates compare the amount of income reported to the tax authorities by the richest 10 (or 1) percent of individuals (or 
families) to an estimate of total personal income in the same year taken from a country's national accounts. ${ }^{11}$ Both the numerator and the denominator of this ratio are subject to error. The numerator will be understated if tax avoidance or evasion is common. ${ }^{12}$ The denominator is likely to be less reliable prior to 1945 , when national income estimates are less precise. Where possible, both the numerator and denominator exclude capital gains.

Nevertheless, the top incomes data are likely to be subject to less measurement error than traditional data sources, such as the Deininger-Squire database (of course, the LIS data is an obvious exception). Indeed, previous research - notably Atkinson and Brandolini (2001) - has questioned the reliability of the Deininger-Squire inequality estimates. According to the Deininger and Squire "accept series", for example, the Gini coefficient for France declined from 0.49 in both 1956 and 1962 to 0.35 in both 1979 and 1984 (Figure 1). This change is roughly equivalent to the cross-sectional difference between Mexico and the United Kingdom in the Luxembourg Income Study data for 2000). ${ }^{13}$ By contrast, the French top income estimates from tax data suggest that the variation in income inequality over this period was much more modest. As Piketty (2003) notes, "since World War II, income inequality in France (as measured by the top decile income share) appears to have been fluctuating around a constant mean value of about 32-33 percent, with no trend." Other evidence on French inequality in the 1960s and 1970s (eg. the wage dispersion data presented in Concialdi 1997) is also more consistent with the modest fluctuations implied by the top incomes estimates than with the dramatic drop implied by the Deininger-Squire dataset.

The top panel of Table 1 shows the mean income share of the richest 10 per cent of the population (TopShare10) for 1920-39, 1940-59, 1960-79, and 1980-99 in each 
country with data from the relevant period (this summary table omits $1905-19$, for which we have relatively few observations). In six of the seven countries with data for the 1920 s and 1930s TopShare10 was higher during these years than in any subsequent period. The exception is Switzerland, where TopShare10 is remarkably stable throughout the years for which we have data. TopShare10 falls substantially between 1920-39 and 1940-49 in the other five countries with data for both periods. It falls more slowly between 1940-59 and 1960-79 in seven of the nine countries with data for both periods and rises slightly in other two. There is no consistent trend between 1960-79 and 1980-99. TopShare10 fell 4.6 points in Sweden, 3.5 points in the Netherlands, and 2.7 points in France, but it rose more than five points in both the United States and the United Kingdom, and by smaller amounts in Australia and New Zealand.

The bottom panel of Table 1 shows that growth was highest in the 1960s and 1970s, when income concentration was lowest. Conversely, growth was lowest in the 1920 s and 1930s, when income concentration was highest. While these comparisons suggest that reducing inequality may boost growth, cross-country comparisons do not seem to support this notion. In the 1920s and 1930s, the growth rate was about the same in the three countries with above-average inequality (the United States, the Netherlands, and France) as in the four countries with below-average inequality (Germany, New Zealand, Sweden, and Switzerland). In the 1980s and 1990s growth was fastest in Ireland and Spain, perhaps because they started off poorest. Among the other ten countries, TopShare10 was highest in the United States, Canada, and the United Kingdom, and the US and the UK were the only countries besides Ireland and Spain with annual per capita growth above 2 percent. TopShare10 was lowest in Sweden, which grew relatively 
slowly, but no more slowly than Canada. These comparisons can be misleading for a multitude of reasons, but they underscore the fact that simple descriptive statistics do not suggest a consistent causal story.

Analysis of the 1940s and 1950s is complicated by the effects of World War II, which initially reduced both inequality and growth but may also have led to faster growth from 1945 to 1960. Both wars and severe economic downturns also compound measurement problems by reducing national statistical agencies' capacity to collect reliable information (Banerjee and Duflo 2003). Until the 1950s, moreover, estimates of both GDP and total personal income (the denominator used to estimate top income shares from tax data) generally have to be constructed from incomplete data collected for other purposes. For this reason we focus primarily on the relationship between inequality and growth since 1960 .

To give some sense of this relationship, Figure 2 plots TopShare10 against a 5 year moving average of the growth rate for the post-1960 years. Trends in TopShare10 are far smoother than trends in GDP growth, even though we show GDP growth as a five year moving average. This is one reason for using five year growth windows.

\section{Identification Strategy}

We use panel models to estimate the effect of top income shares on growth. Our primary estimates come from a fixed effects model like that of Forbes (2000). Growth is estimated over five year windows that begin in year $t$ and run through $t+4$. Each independent variable is measured one year before the growth window commences, in $t-1$. The model therefore has the form: 


$$
\text { Growth }_{i, p}=\beta_{1} \text { TopShare }_{i, t-1}+\beta_{2} \text { Income }_{i, t-1}+\alpha_{i}+\eta_{t}+\varepsilon_{i, p}
$$

where Growth $_{i, p}$ is average annual per capita growth for country $i$ during period $p$, the first year of period $p$ is $t$, TopShare $_{i, t-1}$ is our measure of income inequality in the year before the growth window opens $(t-1)$, Income $_{i, t-1}$ is the natural logarithm of per capita GDP in the same year, $\alpha_{i}$ and $\eta_{t}$ are vectors of fixed country and year effects, and $\varepsilon_{i, p}$ is the error term. In our preferred models we estimate the dependent variable $\left(\right.$ Growth $\left._{i, p}\right)$ over a five year window, but we also test the robustness of our results by measuring growth on an annual basis. ${ }^{14}$

While the use of five year growth windows reduces the effect of serial correlation on our standard errors, we also cluster standard errors at the country level, effectively allowing for an arbitrary variance-covariance matrix within each country. As Bertrand, Duflo and Mullainathan (2004) point out, this is analogous to applying a Newey-West correction (Newey and West 1987) in a panel context, allowing all lags to be potentially important. Bertrand, Duflo and Mullainathan's empirical findings suggest that our cluster-robust standard errors are slightly too small. ${ }^{15}$ However, previous papers in this literature make no such adjustment, so our standard errors are more conservative than those in the earlier literature.

Our post-1960 models augment equation 1 with the same control variables that Perotti (1996) and Forbes (2000) use: a measure of market distortions (the price level of investment relative to the United States) and the average years of secondary schooling completed by adult men and women. ${ }^{16}$ Since our panel is limited to industrialized nations, we also control for average years of higher education among adult men and women. In 
section VI we also present a robustness check that controls for the top marginal tax rate in the five countries for which we have such data. Our measures of the price of investment and adult educational attainment are only available in years divisible by five (1960, $1965 \ldots 1995)$, so we use growth windows that start in the following year $(1961-65,1966-$ 70...1996-2000). For example, we estimate the effect of TopShare10 and TopShare1 in 1960 on a country's average annual economic growth from 1961 to 1965 , and so on.

While the fixed effects model in equation 1 is our preferred specification, we also include random effects estimates for comparison. The random effects estimates are more efficient, because they also utilize the cross-sectional variation in the data, but if the country-specific effects are correlated with other right hand variables, the random effects estimates will be inconsistent. We use Hausman tests to check this independence assumption.

We assess the importance of lags using a variant of equation 1, in which we measure growth using a one year rather than a five year window and use inequality measures lagged by $n$ years:

$$
\text { Growth }_{i, t}=\gamma_{1} \text { TopShare }_{i, t-n}+\gamma_{2} \text { Income }_{i, t-n}+\alpha_{i}+\eta_{t}+\varepsilon_{i, t}
$$

We estimate equation 2 using various combinations of lags, ranging from one to ten years (denoted $t-1 \ldots t-10)$. To gauge the overall effect of lagged inequality on growth, we calculate the linear sum of the lagged inequality coefficients. Although this approach allows us to exploit more of the variation in our data, it may also compound the effects of measurement error by emphasizing errors related to the timing of relationships (see Barro 2000). ${ }^{17}$ 
Interpretation: It is tempting to interpret the coefficient on the inequality measure in equation $1\left(\beta_{1}\right)$ as estimating the average effect of inequality in year $t-1$ on growth over the next five years. If the level of inequality in $t-1$ were uncorrelated with its level in earlier and later years, this interpretation would be compelling (at least if the model also included all other appropriate controls). In reality, however, our measures of inequality are serially correlated, and while equation 1 implicitly controls the mean level of inequality in a given country for all years on which we have data, it does not control inequality just before or just after $t-1$. The coefficient on TopShare $_{t-1}$ therefore incorporates not only the effect of inequality in $t-1$ but any lagged effects of inequality in earlier years $(t-2 \ldots)$ as well as the subsequent effects of inequality during the first four years of the growth window $(t \ldots t+3)$.

Although inequality in $t-1$ is highly correlated with inequality in earlier years, the next section shows that the coefficients on lagged measures of TopShare10 from $t-2$ to $t$ 10 average out to about zero. For TopShare1, the coefficients on the lagged effects from $t-2$ to $t-10$ tend to be positive, but their sum is still not significant. As a result, the correlation between TopShare10 in $t-1$ and TopShare10 in earlier years should not greatly bias the coefficient on TopShare $10_{t-1}$ in equation 1.

The values of TopShare10 during the first four years of the growth window are, however, likely to influence the average rate of growth during the window. If the lagged effect of TopShare10 on growth persists for only one year, as Section V suggests, the estimated effect of the level of inequality during $t-1$ will depend on the degree to which it predicts the level of inequality between $t$ and $t+3$. 
To estimate this relationship we regress the mean level of TopShare10 between $t$ and $t+3$ on TopShare 10 in $t-1$ using data for 1960-2000 and including country fixed effects. When we do this, the coefficient on TopShare $10_{t-1}$ is $0.904(\mathrm{se}=0.022)$. This estimate suggests that increments and decrements in TopShare10 change fairly slowly. That means we cannot interpret the coefficient on TopShare $10_{t-1}$ as estimating the impact of a one point change in TopShare10 sustained for one year. Instead, we must interpret it as estimating the effect of a slightly smaller increase in TopShare10 sustained over five years. Specifically, if TopShare10 is one point above its long-term average in $t$-1, it will exceed its long term average for the country in question by $0.923([1.000+4 \times 0.904] / 5)$ points between $t-1$ and $t+3$. Assuming lagged effects last only one year, the average annual effect of a one point increase in TopShare $10_{t-1}$ sustained over five years will be roughly $\beta_{1} / 0.923$.

When we use TopShare1 in $t-1$ to predict the mean of TopShare1 between $t$ and $t+3$ (including country fixed effects), the coefficient on TopShare $1_{t-1}$ is 0.929 (se $=$ 0.025). For TopShare1, therefore, the coefficient in equation 1 estimates the effect of an $0.943([1+4 \times 0.929] / 5)$ point increase in TopSharel sustained over five years, and the average annual effect of a one point increase in TopSharel between $t$ and $t+3$ is roughly $\beta_{1} / 0.943$. These estimates suggest that equation 1 underestimates the average effect of one point increase in inequality sustained over five years, but that the downward bias is quite small. Nonetheless, we correct for it when interpreting our results. 


\section{Results}

We begin by presenting estimates from our base specification. As in Forbes (2000), growth is calculated over a five year window and inequality is measured one year prior to the start of the growth window. Panel A of Table 2 presents estimates for the full sample (1905-2000), first with pooled OLS, then with random effects and fixed effects. To account for the possibility that disruptive events such as wars affect both growth and inequality, Panel B of Table 2 re-estimates the models in Panel A excluding the five year windows that cover growth in 1911-20 and 1941-50.

The coefficients on the logarithm of initial income are always negative in Table 2 . The coefficients on the inequality measures are also negative and significant in the pooled OLS models. (This is consistent with the early cross-sectional literature on inequality and growth.) However, three of the four coefficients on the inequality measures become insignificant when we add country and year fixed effects, and the fourth coefficient (Panel A, Column 6) is significant only at the 10 per cent level. When we exclude 191120 and 1941-50 in Panel B, the coefficient on inequality becomes very small, statistically insignificant, and positive. These results suggest that there is no consistent robust relationship between inequality and near-term growth for the $20^{\text {th }}$ century as a whole.

Although it is possible that changes in inequality had no effect on growth over this long period, it is also possible that the relationship is just hard to detect during the first half of the twentieth century. Growth and inequality are probably not as precisely measured in that period, and while Panel B of Table 2 excludes 1911-20 and 1941-50, the postwar recoveries continued in the 1920s and 1950s, perhaps further obscuring the effect of inequality. The Great Depression of the 1930s may have had a similar effect. 
Table 3 therefore presents estimates for the post-1960 period, when there were no major wars or depressions and when the data are presumably better. When we measure inequality using the income share of the richest 10 per cent, its estimated effect on growth since 1960 is positive and statistically significant at conventional levels with most estimation techniques. Our preferred specification is in column 6, which includes country and year fixed effects plus time-varying controls. In this specification, TopShare10 is positively and significantly related to growth, with a coefficient of 0.112 . In Panel B, which replaces TopShare10 with TopShare1, the coefficients are about as large as those for TopShare10 in Panel A, but because the standard errors are much larger the coefficients are seldom significant.

Although our preferred specifications include both country and year fixed effects, Table 3 also shows pooled OLS and random effects specifications for comparison. While the coefficients on top income shares are always positive in these specifications, they tend to be smaller and less statistically significant than in the fixed effects models. Unsurprisingly, the estimated coefficient on inequality is more sensitive to the inclusion of control variables in the pooled OLS and random effects models than in the fixed effects models, suggesting that omitted country characteristics bias the coefficient on inequality downward in those models.

Hausman specification tests seldom reject the hypothesis that the differences between the fixed effects and random effects models are due to chance - the exception being column 4 in Panel A. However, the hypothesis that stable but unmeasured differences between countries affect both growth and inequality seems to us more 
plausible from a theoretical viewpoint than the hypothesis that there are no such differences, so we prefer the fixed effects estimates.

Lagged effects: Our preferred specification does not include controls for the effect of inequality more than one year before the growth window opens. To see if longer lags are important, we now use the same sample and the same independent variables as in Table 3 but estimate growth for single years rather than five-year intervals and add lags of 2 to 10 years. Tables 4 and 5 show the results for TopShare10 and TopShare1 respectively. Because the values of top income shares are serially correlated, the standard errors increase dramatically as we add more lags to our models, and the point estimates become less stable. In Table 4, for example, the point estimate for $t-5$ ranges from 0.069 in column 2 to 0.286 in column 4 .

Nonetheless, the positive effect of income inequality on growth is consistently strongest in the first year after inequality is measured. Looking first at the estimates for TopShare10 in Table 4, the coefficient on the 1-year lag in column 1 is much larger than the coefficient on the 5-year lag in column 2. In column 3, which includes five sequential lags, the coefficient on the 1-year lag is 0.221 , while to the sum of the coefficients on the 2 to 5 year lags is -0.034 . In column 4 , which includes ten sequential lags, the coefficient on the 1-year lag is 0.281 , while the sum of the coefficients on the 2 to 9 year lags is $0.028(\mathrm{se}=0.196)$. Nonetheless, the F-test for the joint significance of these nine lags (shown in the bottom row of Table 4$)$ is significant $(p=0.022)$, implying that while the mean of the nine coefficients is not significant their variance is greater than we would expect by chance. However, since their mean is close to zero, ignoring these lags should not appreciably bias the estimated coefficient on TopShare $10_{t-1}$. 
Table 5 shows analogous estimates for TopShare1. The standard errors on the lags are even larger than in Table 4, and the point estimates are more volatile. Nonetheless, the basic story is fairly similar to that for TopShare10. Comparing columns 1 and 2, the coefficient on the 1-year lag is again much larger than the coefficient on the 5-year lag. In column 3 , the coefficient on the 1 -year lag is 0.309 , while the coefficients on the 2 to 5 year lags sum to $-0.119(\mathrm{se}=0.235)$. In column 4 , the coefficient on the 1 year lag falls to 0.154 , while the coefficients on the 2 to 10 year lags sum to 0.243 ( $\mathrm{se}=$ 0.350). This is the only instance in which the point estimates for the lagged effects of inequality after the first year are large enough to be of substantive importance, but their sum does not differ significantly from zero, and the F-test indicates that they are not jointly significant.

Taken together, Tables 4 and 5 suggest that once inequality in year $t-1$ is controlled, lagged values of inequality in earlier years add little useful information. This somewhat surprising result should not be over generalized. It may not hold for broader measures of inequality that capture variation within the bottom nine deciles, for periods when the level of inequality is more volatile than it is in this sample, or for poorer countries. The apparently minor impact of lags in this sample does, however, simplify the task of interpreting the coefficients on top income shares in Tables 3 and 4.

If the lagged effects of TopShare10 fluctuate around zero after the first year, the cumulative impact of a sustained increase in inequality should closely approximate the average effect of inequality in year $t-1$ on growth in year $t$ multiplied by the number of years for which the increase is sustained. In our preferred specification (Model 6 in Table 3), for example, the coefficient on TopShare10 is 0.112 . Since a one point increase 
in TopShare $10_{t-1}$ implies an average increase of 0.923 in TopShare10 between $t-1$ and $t+3$, the estimated first year effect of a one point change in TopShare10 is to increase GDP by $0.121(0.112 / 0.923)$ per cent. ${ }^{18}$ If a one point increase in TopShare10 were sustained over 10 years, per capita GDP at the end of ten years would typically be 1.22 $\left(1.00121^{10}-1\right)$ per cent higher than if TopShare 10 had not changed. If a 10 point increase in TopShare10 were sustained for ten years, GDP would be 12.2 per cent higher than if TopShare10 had not changed. The estimated effect of a 10 point rise TopShare1 sustained for ten years is quite similar (10.7 percent), but it has a larger standard error.

\section{Robustness Checks}

We now investigate the sensitivity of our conclusions to six potential sources of error: our assumption that changes in inequality have linear effects, our particular choice of inequality measures, the absence of controls for top tax rates, outliers, weighting countries only by the number of years for which we have data, and relying on Maddison $(2003,2007)$ for estimates of per capita GDP.

Do changes in inequality have linear effects? Using a sample that includes both rich and poor countries, Banerjee and Duflo (2003) find evidence that both increases and decreases in the Gini coefficient reduce the rate of economic growth. To investigate this possibility we first transform all the independent variables in Table 3 into changes between $t-6$ and $t-1$ as Banerjee and Duflo do. Because we are now taking firstdifferences, we also drop our country fixed effects. Columns 1 and 3 of Table 6 show the coefficients of changes in TopShare10 and TopSharel between $t-6$ and $t-1$ when we predict average annual GDP growth between $t$ and $t+4$. 
Next, we split the 5-year change in inequality into two separate variables. The first variable takes the value of the change if inequality rose and is zero otherwise. The second variable takes the value of the change if inequality fell and is zero otherwise. If Banerjee and Duflo's hypothesis applies in our sample, the coefficients on these variables should both be negative. That is not the case. The coefficients on increases in TopShare10 and TopShare1, shown in columns 2 and 4 of Table 6, are both positive and highly significant - the opposite of what Banerjee and Duflo's findings predict. This difference may reflect the fact that our sample is limited to rich countries or that our inequality measures are limited to the top of the distribution. The coefficients on reductions in TopShare10 or TopShare1, also shown in columns 2 and 4, are insignificant and close to zero, but their 95 per cent confidence intervals include fairly large negative values, so they are not necessarily inconsistent with Banerjee and Duflo's findings. ${ }^{19}$

In contrast to Banerjee and Duflo, our preferred models assume that changes in inequality have linear effects. If that were the case, the coefficients on increases and decreases in inequality should have the same sign and be of the same magnitude. The magnitudes of the coefficients on increases and decreases in inequality obviously differ in Table 6, and for TopSharel even the signs differ. However, the standard errors of these coefficients are so large that we cannot reject the hypothesis that their true values are equal. That means we cannot reject the hypothesis that changes in inequality have linear effects. $^{20}$

Alternative measures of inequality. We have estimated the effect of inequality using the income shares of the top 10 per cent and the top 1 per cent. However, about one-third of the income received by the top 10 per cent goes to the top 1 per cent. Thus it 
is potentially more instructive to split the top 10 per cent's share into two nonoverlapping components: the share received by the top 1 per cent and the share received by the next 9 per cent. Table 7 shows the results when we include both of these measures in a fixed effects specification. The top 1 per cent's share is never both positively and significantly related to the growth rate. Indeed, the relationship is negative and significant for the full sample. By contrast, the share of the next 9 per cent is positively and significantly related to growth in three of the four specifications. In our preferred specification (column 4), the coefficient on the next 9 per cent's share $(0.239)$ is about twice as large as the coefficient on the share of the top 10 per cent $(0.112)$ in Column 6 of Panel A in Table 3. While the standard errors are considerably larger in Table 7 than in Table 3, much of this difference derives from the inclusion of two correlated inequality measures in the same regression. ${ }^{21}$ When we drop the share of the top 1 per cent and replace TopShare 10 in column 6 of Table 3 with the share of the those between the $90^{\text {th }}$ and $99^{\text {th }}$ percentiles, the coefficient rises from $0.112(\mathrm{se}=0.016)$ to $0.210(\mathrm{se}=0.025)$, which is still significant at the 1 per cent level.

Most previous studies of inequality and growth have used Gini coefficients rather than top income shares. To see how our results change if we use Gini coefficients in our sample of countries, we draw on two data sources. For comparability with Forbes (2000), we first use the Deininger and Squire (DS) 'accept' series. Then, taking account of Atkinson and Brandolini's critique of those data, we use Gini coefficients from the Luxembourg Income Study (LIS). ${ }^{22}$ Table 8 shows our results. The coefficients on the Gini are positive in all specifications, but because we have relatively few observations, the standard errors are quite large and the coefficients on the Gini are never significant. 
The Forbes sample closest to ours covers countries with per-capita GNP above $\$ 6000$. There, the coefficient on the Gini is 0.0022 (Forbes 2000, Table 5, Row 11), which is an order of magnitude smaller than the coefficients in our Table 8 .

Top tax rates. High marginal tax rates are negatively related to top income shares (Atkinson and Leigh 2007b). Many theories suggest that high marginal tax rates also reduce economic growth. The positive relationship between top income shares and growth since 1960 could therefore be driven by the fact that lowering taxes raises both top income shares and GDP growth. We have annual data on top marginal tax rates for the five countries covered by Atkinson and Leigh's study: Australia, Canada, New Zealand, the United Kingdom, and the United States. Table 9 presents results for these five countries using the same specification as column 6 of Table 3 . Columns 1 and 3 of Table 9 show estimates with the top tax rate excluded. Columns 2 and 4 show estimates with it included. The coefficient on the top tax rate in $t-1$ when we use it to predict GDP growth from $t$ to $t+4$ is small and statistically insignificant, suggesting that top tax rates are unlikely to explain much of the linkage between top income shares and growth. Comparing columns 1 and 2 supports this conclusion. Controlling top tax rates actually raises the coefficient on TopShare10 slightly (from 0.125 to 0.148 ). The coefficient on TopShare1 falls, but only from 0.171 to 0.169 .

Outliers. To assess the importance of outliers we reran our preferred models (shown in column 6 of Table 3 ) twelve times, dropping a different country each time. No single country appears to have a disproportionate impact on the relationship between TopShare10 and growth, and the coefficient on TopShare10 only varies from 0.10 to 
0.14. In each case the relationship between inequality and growth also remains significant at the 1 per cent level.

When we perform the same exercise for TopSharel, however, the coefficient ranges from 0.07 to 0.13 . While the relationship is usually insignificant, it becomes significant at the 5 per cent level if either Ireland or New Zealand is excluded. Ireland and New Zealand are our two smallest countries, accounting for only 1.2 per cent of the 12 country sample's 610 million inhabitants in 2000. Our finding that the income share of the top one per cent is insignificant should therefore be treated cautiously.

Weighting. Because growth rates vary more across small countries than large countries, we also tried weighting each country by its population in 1960. Population weighting reduces the coefficient on TopShare10 in our preferred specification from $0.112(\mathrm{se}=0.025)$ to $0.103(\mathrm{se}=0.015)$ and increases the coefficient on TopSharel from 0.095 ( $\mathrm{se}=0.057)$ to 0.154 ( $\mathrm{se}=0.028)$. Thus, while TopSharel is statistically insignificant in column 6 of Table 3 , it is significant at the 1 per cent level when countries are weighted by their 1960 population. This reinforces our caution against assuming that because the coefficient of TopSharel is insignificant in our preferred specification its true effect is negligible.

Data sources. We use growth rates taken from Maddison (2003, 2007). Maddison measures changes in GDP per capita by converting all national estimates to 1990 International Geary-Khamis dollars. For the years since 1960 we can replace Maddison's estimates with estimates from the World Development Indicators database and measure per capita GDP in constant local currency units. After making this change, the coefficient on TopShare10 in our preferred specification rises from $0.112(\mathrm{se}=0.025)$ to $0.125(\mathrm{se}=$ 
$0.022)$, and the coefficient on TopSharel rises from $0.095(\mathrm{se}=0.057)$ to $0.126(\mathrm{se}=$ 0.058). When we use the World Development Indicators estimate of per capita GNI rather than GDP (again measured in constant local currency units), the coefficient on TopShare10 in our preferred specification rises to $0.127(\mathrm{se}=0.026)$, while the coefficient on TopShare1 rises to 0.159 ( $\mathrm{se}=0.067$ ). Thus while TopSharel is not significant at conventional levels in column 6 of Table 3 , it is significant at the 10 per cent level when we measure GDP changes in local currency units and at the 5 per cent level when we replace GDP changes with GNI changes in local currency units.

\section{Trickle-down effects}

Our preferred estimate is that a 1 point rise in the share of the richest 10 per cent sustained over five years raises average annual growth by 0.121 percentage points. One obvious question is whether such an increase in growth is large enough to raise the incomes of households in the bottom 90 percent of the distribution as well as those in the top 10 percent. That is, if the income share of the richest 10 per cent rises by 1 percentage point, will the resulting increase in growth be large enough to compensate the bottom 90 per cent of the distribution for the fact that their share of total income has fallen by 1 percentage point? Or, to put it differently, does an increase in top income shares have a 'trickle-down effect' that raises absolute incomes for those further down in the distribution?

Back-of-the-envelope calculations suggest that the answer to this question is "not for a long time.' In the United States, for example, TopShare10 averaged 32.0 percent between 1960 and 1979 and 42.0 percent between 1995 and 2004. Our preferred model 
implies that a sustained 10 point increase in the level of TopShare10 makes annual GDP growth 1.21 percentage points higher than it would be if TopShare10 were 10 points lower. ${ }^{23}$ If personal income rises at the same rate as GDP, annual growth in personal income will also be 1.21 points higher.

However, raising the top decile's share of income from 32 to 42 per cent also lowers the bottom nine deciles' total share from 68 to 58 per cent. If the entire increase in inequality occurred in a single year, the mean personal income of the bottom nine deciles in the following year would be 13.7 per cent lower $([58 / 68] \times[1.021]-1)$ than if inequality had not risen and growth had not accelerated. The cost of higher inequality diminishes over time, however, because the effects of higher growth are cumulative. If the top decile's share remains at 42 per cent for 10 years, total personal income will be $1.0121^{10}=1.128$ times higher than it would have been if TopShare 10 had been only 32 per cent. As a result, the mean income of the bottom nine deciles will be only 3.8 per cent $([58 / 68] \times[1.128]-1)$ lower than if inequality had not risen. After 13 years the bottom nine deciles reach the 'breakeven' point where faster growth in total personal income finally offsets the fact that they are now getting a smaller share of the total. ${ }^{24}$ If a higher level of inequality continues to yield higher growth indefinitely, our simulation implies that the absolute incomes gains of the bottom nine deciles will become progressively larger. However, our data cannot tell us whether such long-term projections are realistic.

Another way to think about this question is to simulate the impact of TopShare10's actual trajectory in United States, again assuming that a one point increase in the level of TopShare10 raises growth by 0.121 per cent for as long as the higher level of TopShare10 persists. Because the top decile's share hardly changed between 1960 and 
1970, we focus on the period since 1970. The solid lines in Figure 3 show the observed trend in mean income among families with incomes above and below the $90^{\text {th }}$ percentile. The dashed lines show the predicted trend if TopShare10 had remained at its 1970 level.

This simulation suggests that if inequality had not risen the mean income of the top decile would have been $49 \log$ points lower than it was in 2003 . The picture is very different for the bottom nine deciles. From 1970 through 1985 the growth-promoting and share-reducing effects of rising inequality roughly offset one another. However, TopShare10 rises almost four per cent between 1986 and 1989. As a result, the mean income of the bottom nine deciles over the ensuing decade is 4 to 7 points lower than it would have been if inequality had remained at its 1970 level. From 1998 to 2003, in contrast, the income share of the top decile was high but stable. As a result, the growthpromoting effects of the higher level of inequality began to offset the share-reducing effect. Indeed, the simulation suggests that by 2001 the growth-promoting effects of redistribution had pushed the mean income of the bottom nine deciles above what it would have been if their share of total income had not fallen from 68 to 58 per cent over the previous thirty years.

Naturally, all the foregoing calculations are overly simple. The estimates have large sampling errors. They ignore the fact that changes in the income share of the bottom nine deciles often proxy changes in the distribution of income within the bottom nine deciles. They also assume that a change in inequality has the same effect regardless of its cause, which seems unlikely. How we think about this question also depends on the type of social welfare function we have in mind. But at the very least, the 95 per cent confidence intervals for our preferred estimates appear to rule out the claim that a rise in 
top income shares causes a large short-term increase or decrease in economic growth. The claim that inequality at the top of the distribution either benefits or harms everyone therefore depends on long-term effects that we cannot estimate very precisely even with these data.

\section{Conclusion}

This paper has used panel techniques to estimate the relationship between economic growth and inequality, as measured by top incomes shares. Our results support Forbes's (2000) conclusion that increases in inequality lead to more growth. There appears to be some trickle-down effect in the long run, but since the impact of a change in inequality on economic growth is quite small, it is difficult to be sure from our estimates whether the bottom 90 per cent will really be better off or not.

We could not investigate the impact of inequality within the bottom nine deciles of the distribution. But if Voitchovsky (2005) is right that inequality between the bottom and the middle of the distribution (relative poverty) lowers growth while inequality between the top and the middle (relative affluence) raises growth, our measures of inequality presumably overestimate the positive effects of across-the-board increases in inequality on growth. 


\section{References}

Aghion, P., Caroli, E. and García-Peñalosa, C. (1999), 'Inequality and Economic Growth: The Perspective of the New Growth Theories', Journal of Economic Literature, 37(4): 1615-1660

Akerlof, G.A. and Yellen, J.L. (1990), 'The Fair-Wage Hypothesis and Unemployment', Quarterly Journal of Economics, 105: 255-283.

Alesina, A. and D. Rodrik, (1994), 'Distributive Politics and Economic Growth' Quarterly Journal of Economics 109(2): 469-490.

Alvaredo, F. and Saez, E. (2006), 'Income and wealth concentration in Spain in a historical and fiscal perspective.' CEPR Discussion Paper No 5836.

Atkinson, A. B. (2007), 'Top incomes in the United Kingdom over the twentieth century.' In Top Incomes over the Twentieth Century: A Contrast Between Continental European and English Speaking Countries (ed. A. Atkinson and T. Piketty), pp.82-140. Oxford: Oxford University Press.

Atkinson, A.B. and Brandolini, A. (2001), 'Promise and Pitfalls in the Use of 'Secondary' Data-Sets: Income Inequality in OECD Countries as a Case Study' Journal of Economic Literature 39(3): 771-799.

Atkinson, A. B. and Leigh, A. (2005), 'The distribution of top incomes in New Zealand.' Australian National University CEPR Discussion Paper 503.

Atkinson, A. B. and Leigh, A. (2007a), 'The Distribution of Top Incomes in Australia.' Economic Record, 83(262): 247-261. 
Atkinson, A.B. and Leigh, A. (2007b), 'The Distribution of Top Incomes in Five AngloSaxon Countries over the Twentieth Century', mimeo, Australian National University.

Atkinson, A.B. and Piketty, T., Eds. (2007), Top Incomes over the Twentieth Century: A Contrast Between Continental European and English Speaking Countries. Oxford: Oxford University Press.

Atkinson, A.B. and Piketty, T., Eds. (2009), Top Incomes Over the Twentieth Century: Volume II - A Global Perspective. Oxford: Oxford University Press.

Banerjee, AV and E Duflo, (2003), 'Inequality and Growth: What Can the Data Say?' Journal of Economic Growth 8: 267-299.

Barro, R. J. (2000), 'Inequality and Growth in a Panel of Countries' Journal of Economic Growth 5: 5-32.

Bénabou, R. (2005), 'Inequality, Technology and the Social Contract' In P. Aghion and S.N. Durlauf (eds), Handbook of Economic Growth, Elsevier, Amsterdam, Volume 1, Part 2, 1595-1638.

Bertrand, M., Duflo, E., and Mullainathan, S., (2004), 'How Much Should We Trust Differences-in-Differences Estimates?' Quarterly Journal of Economics, 119(1): 249275.

Bowley, A. L. (1914) 'The British super-tax and the distribution of income'. Quarterly Journal of Economics, 28, 255-268. 
Card, D. and JE DiNardo, (2002), 'Skill-Biased Technological Change and Rising Wage Inequality: Some Problems and Puzzles' Journal of Labor Economics 20 (October): $733-83$

Concialdi, P. (1997), 'Income distribution in France: The mid 1980s turning point', In P. Gottschalk, B. Gustafson, and E. Palmer (ed), Changing Patterns in the Distribution of Economic Welfare: An International Perspective, Cambridge University Press, Cambridge, 239-264.

Deininger, K. and N. Squire (1996), 'A New Data Set Measuring Income Inequality' World Bank Economic Review 10(3): 565-91.

Dell, F. (2007), 'Top incomes in Germany throughout the twentieth century: 1891-1998.' In Top Incomes over the Twentieth Century: A Contrast Between Continental European and English Speaking Countries (ed. A. Atkinson and T. Piketty), pp.365425. Oxford: Oxford University Press.

Dell, F., Piketty T. and Saez, E. (2007), 'Income and wealth concentration in Switzerland over the 20th century.' In Top Incomes over the Twentieth Century: A Contrast Between Continental European and English Speaking Countries (ed. A. Atkinson and T. Piketty), pp.472-500. Oxford: Oxford University Press.

Eriksson, T. (1999), 'Executive Compensation and Tournament Theory: Empirical Tests on Danish Data', Journal of Labor Economics, 12: 775-782.

Fajnzylber, P, Lederman, D, and Loayza, N. (2002). 'Inequality and Violent Crime'. Journal of Law and Economics. 45(1): 1-40. 
Forbes, KJ (2000), 'A Reassessment of the Relationship Between Inequality and Growth' American Economic Review 90(4): 860-887.

Galor, O. and Zeira, J. (1993) 'Income Distribution and Macroeconomics', Review of Economic Studies, 60(1): 35-52

Glaeser E., Scheinkman J. and Shleifer A. (2003) 'The injustice of inequality' Journal of Monetary Economics, 50(1): 199-222.

Heyman, F. (2005), 'Pay Inequality and Firm Performance: Evidence from Matched Employer-Employee Data', Applied Economics, 37: 1313-1327.

Kuznets, S. (1953), Shares of Upper Income Groups in Income and Savings, National Bureau of Economic Research, New York.

Lazear, E. and Rosen, S. (1981), 'Pay Inequality and Industrial Politics', Journal of Political Economy, 87: 1261-1284.

Leigh, A. (2007) 'How Closely Do Top Income Shares Track Other Measures of Inequality?' Economic Journal, 117: F589-F603.

Leigh, A. (2009) 'Top Incomes' in W. Salverda, B. Nolan, and T. Smeeding (eds.), Handbook on Economic Inequality, Oxford, Oxford University Press, 150-176.

Leigh, A. and Posso, A. (2009) 'Top Incomes and National Savings' Review of Income and Wealth, 55(1): 57-74.

Lindert, P. (2004) Growing Public: Social Spending and Economic Growth Since the Eighteenth Century, Cambridge University Press. 
Main, B., O’Reilly, C.A., and Wade, J. (1993) 'Top Executive Pay: Tournament or Teamwork?' Journal of Economic Behavior and Organization. 15: 237-255

Mauro, P (1995) ‘Corruption and Growth’ Quarterly Journal of Economics, 110(3): 681712.

Maddison, A. (2003) The World Economy: Historical Statistics, OECD Development Centre, Paris.

Maddison, A. (2007) 'Historical Statistics for the World Economy: 1-2003 AD'. Excel file downloaded from http://www.ggdc.net/maddison/ on August 30, 2007.

Newey, W. and West, K. D., (1987), 'A Simple, Positive Semi-Definite, Heteroskedasticity and Autocorrelation Consistent-Covariance Matrix,' Econometrica, 55: 703-708.

Nolan, B. (2007), 'Long-term trends in top income shares in Ireland.' In Top Incomes over the Twentieth Century: A Contrast Between Continental European and English Speaking Countries (ed. A. Atkinson and T. Piketty), pp.501-530. Oxford: Oxford University Press.

Perotti, R (1996), 'Growth, Income Distribution and Democracy' Journal of Economic Growth 1(2): 149-187.

Persson, T and G Tabellini, (1994), 'Is Inequality Harmful for Growth?' American Economic Review 84(3): 600-621.

Piketty, T. (2003), 'Income Inequality in France, 1901-1998' Journal of Political Economy 111(5): 1004-1042. 
Piketty, T. (2007), 'Income, wage and wealth inequality in France, 1901-1998.' In Top Incomes over the Twentieth Century: A Contrast Between Continental European and English Speaking Countries (ed. A. Atkinson and T. Piketty), pp.43-81. Oxford: Oxford University Press.

Piketty, T and E Saez (2006a), 'The Evolution of Top Incomes: A Historical and International Perspective' AEA Papers and Proceedings 96(2): 200-205.

Piketty, T. and Saez, E. (2006b), 'Income inequality in the United States.' Tables and Figures updated to 2004 in Excel format, http:/emlab.berkeley.edu/users/saez/ (downloaded 6 December 2006).

Roine, J., Vlachos, J., and Waldenström, D. (2007), 'What Determines Top Income Shares? Evidence from the Twentieth Century' IFN Working Paper No. 721, Research Institute of Industrial Economics, Stockholm.

Roine, J. and Waldenström, D. (2008). 'The evolution of top incomes in an egalitarian society: Sweden, 1903-2004'. Journal of Public Economics 92: 366-387.

Salverda, W. and Atkinson, A. B. (2007), 'Top incomes in the Netherlands over the twentieth century.' In Top Incomes over the Twentieth Century: A Contrast Between Continental European and English Speaking Countries (ed. A. Atkinson and T. Piketty), pp.426-472. Oxford: Oxford University Press.

Saez, E. and Veall, M. (2005), 'The evolution of high incomes in Northern America: lessons from Canadian evidence.' American Economic Review, 95(3): 831-849. 
Summers, R. and Heston, A. (1991) 'The Penn World Table (Mark 5): An Expanded Set of International Comparisons, 1950-1988.' Quarterly Journal of Economics, 106(2): $327-368$.

Voitchovsky, S. (2005), 'Does the Profile of Income Inequality Matter for Growth?: Distinguishing Between the Effects of Inequality in Different Parts of the Distribution’ Journal of Economic Growth 10(3): 273-296. 
Figure 1: How Trends in Income Inequality Vary Across Data Sources France as a Case Study

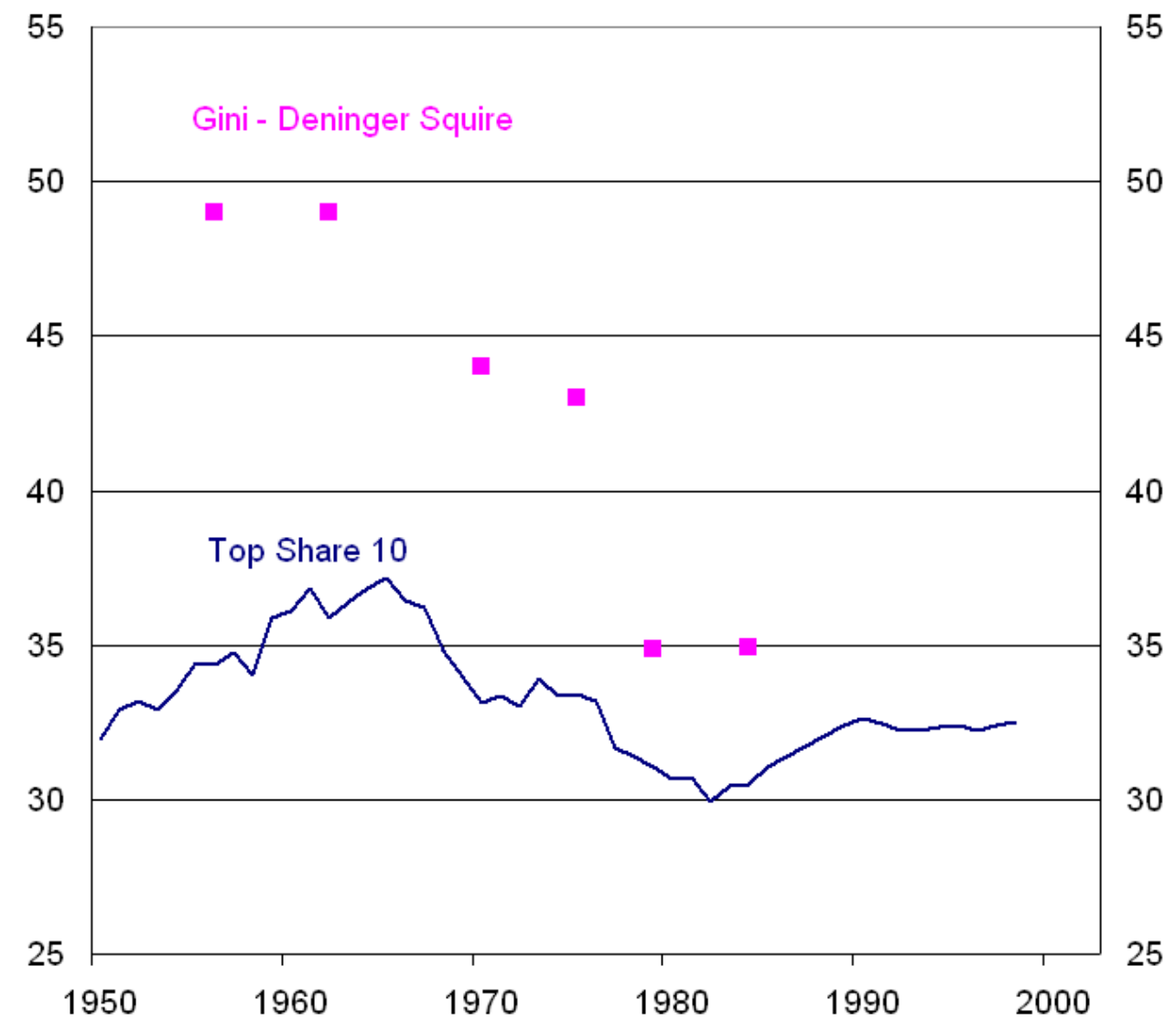


Figure 2: Top Incomes and Growth Since 1960
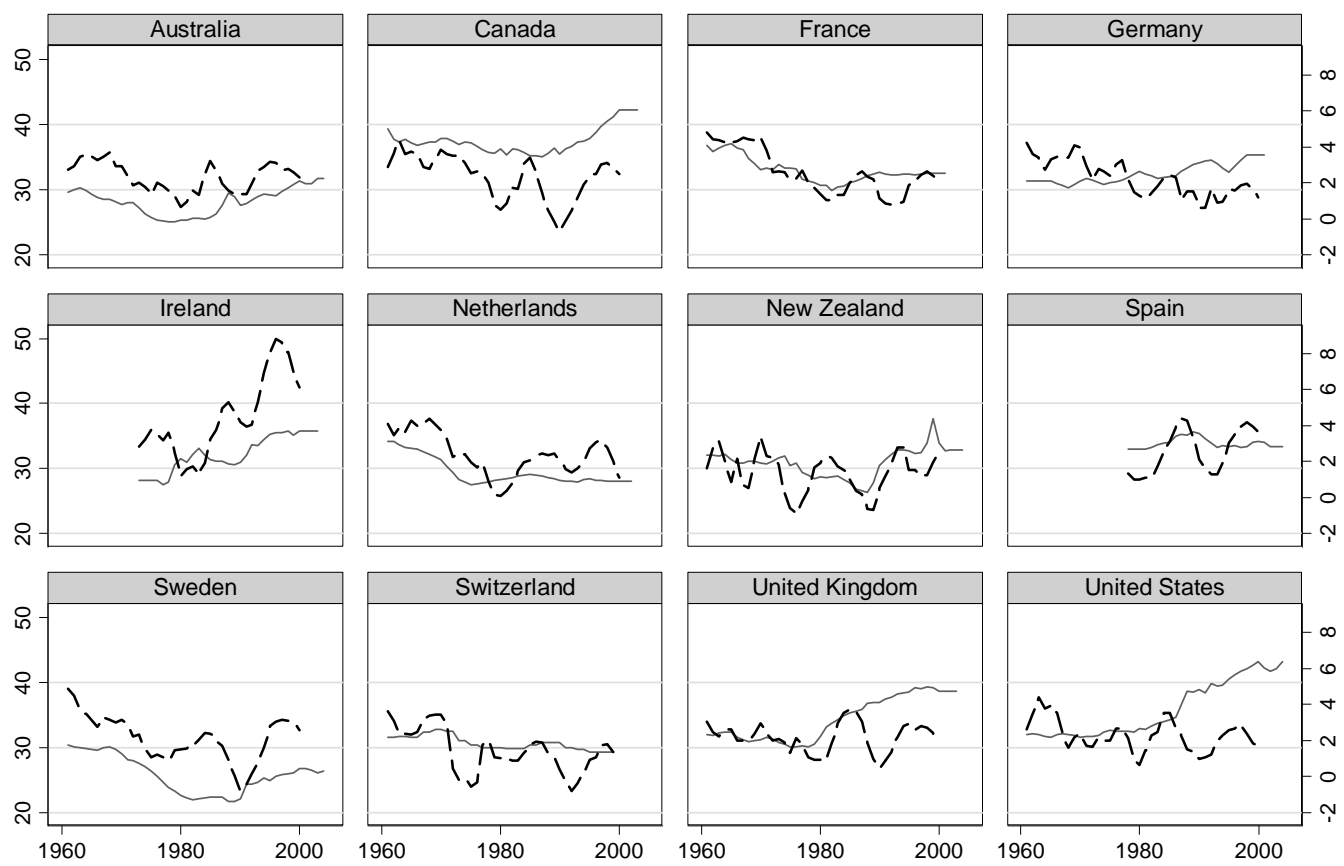

Top $10 \%$ share (left scale) 
Figure 3: Trends from 1970 to 2003 for the Income of the Top Decile and the Bottom Nine Deciles in the United States: Observed Means versus Predicted Means if the Top Decile's Share Had Stayed at Its 1970 Level

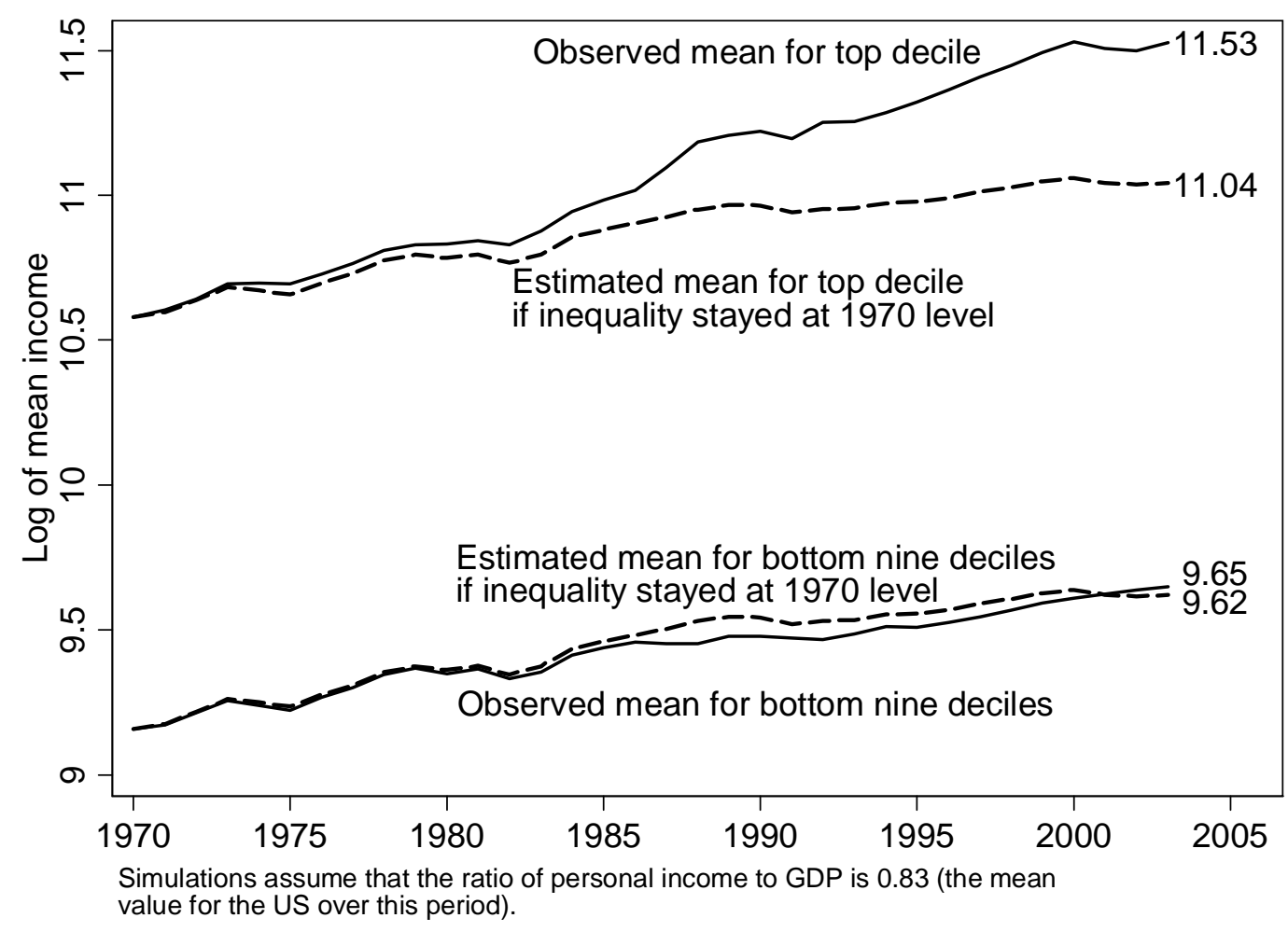




\begin{tabular}{|c|c|c|c|c|}
\hline Period & 1920-1939 & 1940-1959 & $1960-1979$ & 1980-1999 \\
\hline \multicolumn{5}{|c|}{ Income share of the richest $10 \%^{\dagger}$} \\
\hline Australia & -- & 30.05 & 27.83 & 27.84 \\
\hline Canada & -- & 38.59 & 37.30 & 36.95 \\
\hline France & 42.54 & 33.64 & 34.40 & 31.71 \\
\hline Germany & 35.79 & -- & 31.27 & 33.26 \\
\hline Ireland & -- & -- & -- & 32.82 \\
\hline The Netherlands & 42.84 & 38.73 & 31.46 & 27.92 \\
\hline New Zealand & 35.28 & 30.24 & 31.02 & 30.36 \\
\hline Spain & -- & -- & -- & 34.00 \\
\hline Sweden & 37.30 & 31.48 & 28.13 & 23.53 \\
\hline Switzerland & 31.20 & 31.75 & 31.42 & 29.93 \\
\hline United Kingdom & -- & 33.41 & 31.18 & 36.57 \\
\hline United States & 43.68 & 33.73 & 32.00 & 37.66 \\
\hline $\begin{array}{l}\text { Sample mean } \\
\text { (Standard deviation) }\end{array}$ & $\begin{array}{l}38.37 \\
(4.73)\end{array}$ & $\begin{array}{l}33.51 \\
(3.22)\end{array}$ & $\begin{array}{l}31.60 \\
(2.74)\end{array}$ & $\begin{array}{l}31.88 \\
(4.22)\end{array}$ \\
\hline \multicolumn{5}{|c|}{$\begin{array}{l}\text { Average annual GDP per capita } \\
\text { growth (per cent) }\end{array}$} \\
\hline Australia & 1.03 & 1.69 & 2.47 & 1.98 \\
\hline Canada & 1.06 & 2.43 & 3.12 & 1.43 \\
\hline France & 2.00 & 2.87 & 3.49 & 1.55 \\
\hline Germany & 3.35 & 1.43 & 3.03 & 1.34 \\
\hline Ireland & -- & 1.41 & 3.41 & 4.38 \\
\hline The Netherlands & 1.37 & 2.38 & 2.89 & 1.80 \\
\hline New Zealand & 0.68 & 2.14 & 1.31 & 1.31 \\
\hline Spain & -0.64 & 1.93 & 5.56 & 2.44 \\
\hline Sweden & 2.97 & 2.71 & 2.67 & 1.43 \\
\hline Switzerland & 1.96 & 3.14 & 1.87 & 0.74 \\
\hline United Kingdom & 1.61 & 0.92 & 2.13 & 2.07 \\
\hline United States & 0.84 & 2.38 & 2.56 & 2.02 \\
\hline Sample mean & 1.48 & 2.12 & 2.87 & 1.87 \\
\hline (Standard deviation) & (1.10) & $(0.66)$ & $(1.86)$ & $(0.91)$ \\
\hline
\end{tabular}

${ }^{\dagger}$ Top incomes are averages for each time period. When there are missing observations, we show period averages only if at least ten observations are available. Data for 1905-19 not shown. 
Table 2: Top Incomes and Growth Over the Twentieth Century Dependent variable: Average annual per capita growth (5 year periods)

Estimation method

\section{Pooled OLS}

[1] [2]
Random Effects

[3]
Fixed Effects

[5]
[6]

Panel A: 1905 - 2000 (including World Wars I and II)

\begin{tabular}{|c|c|c|c|c|c|c|}
\hline \multirow[t]{2}{*}{ Income share of richest $10 \%$} & $-0.085^{*}$ & & -0.024 & & -0.032 & \\
\hline & {$[0.044]$} & & {$[0.040]$} & & {$[0.050]$} & \\
\hline \multirow[t]{2}{*}{ Income share of richest $1 \%$} & & $-0.179 * * *$ & & -0.068 & & $-0.105^{*}$ \\
\hline & & {$[0.050]$} & & {$[0.057]$} & & {$[0.058]$} \\
\hline \multirow[t]{2}{*}{ Log(GDP per capita) } & -0.582 & $-0.928 * * *$ & $-1.968 * * *$ & $-2.284 * * *$ & $-3.026^{* *}$ & $-4.077 * * *$ \\
\hline & {$[0.342]$} & {$[0.297]$} & {$[0.597]$} & {$[0.691]$} & {$[1.253]$} & {$[1.256]$} \\
\hline Country Fixed Effects? & No & No & No & No & Yes & Yes \\
\hline Year Fixed Effects? & No & No & Yes & Yes & Yes & Yes \\
\hline $\mathrm{R}^{2}$ & 0.04 & 0.07 & 0.28 & 0.32 & 0.28 & 0.34 \\
\hline Countries & 12 & 12 & 12 & 12 & 12 & 12 \\
\hline Observations & 156 & 169 & 156 & 169 & 156 & 169 \\
\hline
\end{tabular}

Panel B: 1905 - 2000 (excluding World Wars I and II)

\begin{tabular}{lcccccc}
\hline Income share of richest 10\% & $-0.052^{*}$ & \multicolumn{3}{c}{0.001} & \multicolumn{3}{c}{0.03} & \\
& {$[0.028]$} & & {$[0.024]$} & & {$[0.041]$} & \\
Income share of richest 1\% & & $-0.104^{* *}$ & & 0.005 & & 0.001 \\
& & {$[0.036]$} & & {$[0.041]$} & & {$[0.041]$} \\
Log(GDP per capita) & $-0.575^{*}$ & $-0.857^{* *}$ & $-2.888^{* * *}$ & $-3.740^{* * *}$ & $-3.618^{*}$ & $-4.872^{* *}$ \\
& {$[0.294]$} & {$[0.280]$} & {$[0.716]$} & {$[0.771]$} & {$[1.713]$} & {$[1.665]$} \\
Country Fixed Effects? & No & No & No & No & Yes & Yes \\
Year Fixed Effects? & No & No & Yes & Yes & Yes & Yes \\
$\mathrm{R}^{2}$ & 0.04 & 0.05 & 0.48 & 0.47 & 0.48 & 0.47 \\
Countries & 12 & 12 & 12 & 12 & 12 & 12 \\
Observations & 134 & 144 & 134 & 144 & 134 & 144 \\
\hline
\end{tabular}

Notes: $* * *$ and $* * *$ denote statistical significance at the $10 \%, 5 \%$ and $1 \%$ levels respectively. Robust standard errors, clustered at the country level, in brackets. $\mathrm{R}^{2}$ is the within- $\mathrm{R}^{2}$ for random and fixed effects. 


\begin{tabular}{|c|c|c|c|c|c|c|}
\hline \multicolumn{6}{|c|}{ Table 3: Top Incomes and Growth Since 1960} & Dependent variable: Average annual per capita growth (5 year periods) \\
\hline & [1] & [2] & [3] & [4] & [5] & {$[6]$} \\
\hline & OLS & OLS & $\mathrm{RE}$ & RE & $\mathrm{FE}$ & $\mathrm{FE}$ \\
\hline \multicolumn{7}{|l|}{ Panel A: Top 10\% Share } \\
\hline \multirow[t]{2}{*}{$\overline{\text { Income share of richest } 10 \%}$} & $0.073 * *$ & 0.049 & $0.062^{* * *}$ & 0.037 & $0.110^{* * *}$ & $0.112 * * *$ \\
\hline & {$[0.026]$} & {$[0.032]$} & {$[0.021]$} & {$[0.025]$} & {$[0.016]$} & {$[0.025]$} \\
\hline Log(GDP per capita) & $\begin{array}{c}-1.595 * * * \\
{[0.264]}\end{array}$ & $\begin{array}{c}-1.415^{* * *} \\
{[0.418]}\end{array}$ & $\begin{array}{c}-2.428 * * * \\
{[0.566]}\end{array}$ & $\begin{array}{c}-2.375^{* * *} \\
{[0.743]}\end{array}$ & $\begin{array}{l}-2.271 \\
{[2.917]}\end{array}$ & $\begin{array}{c}-2.1 \\
{[3.017]}\end{array}$ \\
\hline $\begin{array}{l}\text { Investment and Schooling } \\
\text { Controls? }\end{array}$ & No & Yes & No & Yes & No & Yes \\
\hline Country Fixed Effects? & No & No & No & No & Yes & Yes \\
\hline Year Fixed Effects? & No & No & Yes & Yes & Yes & Yes \\
\hline $\mathrm{R}^{2}$ & 0.20 & 0.21 & 0.48 & 0.43 & 0.49 & 0.49 \\
\hline Countries & 12 & 12 & 12 & 12 & 12 & 12 \\
\hline Observations & 89 & 87 & 89 & 87 & 89 & 87 \\
\hline $\begin{array}{l}\text { Hausman Test } \\
\text { H0: Difference in coefficients } \\
\text { not systematic }\end{array}$ & & & 3.07 & 19.86 & & \\
\hline $\mathrm{P}>\mathrm{Chi} 2$ & & & $\mathrm{P}=1.00$ & $\mathrm{P}=0.09$ & & \\
\hline \multicolumn{7}{|l|}{ Panel B: Top 1\% Share } \\
\hline \multirow[t]{2}{*}{ Income share of richest $1 \%$} & 0.067 & 0.049 & 0.06 & 0.057 & $0.136^{* * *}$ & 0.095 \\
\hline & {$[0.059]$} & {$[0.071]$} & {$[0.044]$} & {$[0.061]$} & {$[0.038]$} & {$[0.057]$} \\
\hline Log(GDP per capita) & $\begin{array}{c}-1.615^{* * *} \\
{[0.320]}\end{array}$ & $\begin{array}{c}-1.440 * * * \\
{[0.402]}\end{array}$ & $\begin{array}{c}-2.522^{* * *} \\
{[0.561]}\end{array}$ & $\begin{array}{c}-2.474 * * * \\
{[0.658]}\end{array}$ & $\begin{array}{l}-1.993 \\
{[2.997]}\end{array}$ & $\begin{array}{l}-1.777 \\
{[3.234]}\end{array}$ \\
\hline $\begin{array}{l}\text { Investment and Schooling } \\
\text { Controls? }\end{array}$ & No & Yes & No & Yes & No & Yes \\
\hline Country Fixed Effects? & No & No & No & No & Yes & Yes \\
\hline Year Fixed Effects? & No & No & Yes & Yes & Yes & Yes \\
\hline $\mathrm{R}^{2}$ & 0.16 & 0.20 & 0.46 & 0.42 & 0.47 & 0.46 \\
\hline Countries & 12 & 12 & 12 & 12 & 12 & 12 \\
\hline Observations & 89 & 87 & 89 & 87 & 89 & 87 \\
\hline $\begin{array}{l}\text { Hausman Test } \\
\text { H0: Difference in coefficients } \\
\text { not systematic }\end{array}$ & & & 10.37 & 10.68 & & \\
\hline $\mathrm{P}>\mathrm{Chi} 2$ & & & $\mathrm{P}=0.96$ & $\mathrm{P}=0.63$ & & \\
\hline
\end{tabular}

Notes: $*, * *$ and $* * *$ denote statistical significance at the $10 \%, 5 \%$ and $1 \%$ levels respectively. Robust standard errors, clustered at the country level, in brackets. $\mathrm{R}^{2}$ is the within- $\mathrm{R}^{2}$ for random and fixed effects. Investment and schooling controls are the price level of investment relative to the US at PPP, the average years of secondary education for the male and female adult population, and the average years of post-secondary education for the male and female adult population. 


\begin{tabular}{|c|c|c|c|c|}
\hline \multicolumn{5}{|c|}{ Dependent variable: Per capita growth in year $t$} \\
\hline Income share of richest $10 \%(\mathrm{t}-1)$ & $\begin{array}{c}0.191 * * * \\
{[0.042]}\end{array}$ & & $\begin{array}{c}0.221 \\
{[0.138]}\end{array}$ & $\begin{array}{c}0.281 \\
{[0.213]}\end{array}$ \\
\hline Income share of richest $10 \%(\mathrm{t}-2)$ & & & $\begin{array}{l}-0.001 \\
{[0.266]}\end{array}$ & $\begin{array}{c}-0.132 \\
{[0.257]}\end{array}$ \\
\hline Income share of richest $10 \%(\mathrm{t}-3)$ & & & $\begin{array}{l}-0.128 \\
{[0.203]}\end{array}$ & $\begin{array}{c}-0.093 \\
{[0.342]}\end{array}$ \\
\hline Income share of richest $10 \%(\mathrm{t}-4)$ & & & $\begin{array}{c}0.003 \\
{[0.258]}\end{array}$ & $\begin{array}{c}0.051 \\
{[0.312]}\end{array}$ \\
\hline Income share of richest $10 \%(\mathrm{t}-5)$ & & $\begin{array}{c}0.069 \\
{[0.057]}\end{array}$ & $\begin{array}{c}0.092 \\
{[0.165]}\end{array}$ & $\begin{array}{c}0.286 \\
{[0.366]}\end{array}$ \\
\hline Income share of richest $10 \%(\mathrm{t}-6)$ & & & & $\begin{array}{l}-0.412 \\
{[0.265]}\end{array}$ \\
\hline Income share of richest $10 \%(\mathrm{t}-7)$ & & & & $\begin{array}{c}0.099 \\
{[0.355]}\end{array}$ \\
\hline Income share of richest $10 \%(\mathrm{t}-8)$ & & & & $\begin{array}{c}-0.038 \\
{[0.383]}\end{array}$ \\
\hline Income share of richest $10 \%(\mathrm{t}-9)$ & & & & $\begin{array}{l}-0.165 \\
{[0.288]}\end{array}$ \\
\hline Income share of richest $10 \%(\mathrm{t}-10)$ & & & & $\begin{array}{l}0.432^{* *} \\
{[0.178]}\end{array}$ \\
\hline $\begin{array}{l}\text { GDP, Investment price, and Schooling } \\
\text { Controls? }\end{array}$ & Yes & Yes & Yes & Yes \\
\hline Country Fixed Effects? & Yes & Yes & Yes & Yes \\
\hline Year Fixed Effects? & Yes & Yes & Yes & Yes \\
\hline $\mathrm{R}^{2}$ & 0.40 & 0.38 & 0.49 & 0.57 \\
\hline Countries & 12 & 12 & 12 & 12 \\
\hline Observations & 391 & 391 & 343 & 283 \\
\hline Sum of Top $10 \%$ coefficients (all lags) & & & $\begin{array}{l}0.187 * * * \\
{[0.056]}\end{array}$ & $\begin{array}{l}0.310^{* * * *} \\
{[0.100]}\end{array}$ \\
\hline Sum of Top $10 \%$ coefficients ( $t-2$ to $t-5$ ) & & & $\begin{array}{l}-0.034 \\
{[0.125]}\end{array}$ & \\
\hline Sum of Top $10 \%$ coefficients (t-2 to $t-10)$ & & & & $\begin{array}{c}0.028 \\
{[0.196]}\end{array}$ \\
\hline $\begin{array}{l}\text { F-test for joint significance of lags } \mathrm{t}-2 \text { to } \mathrm{t}-5 \\
\text { [P-value] }\end{array}$ & & & $\begin{array}{c}0.43 \\
{[\mathrm{P}=0.782]}\end{array}$ & \\
\hline $\begin{array}{l}\text { F-test for joint significance of lags } \mathrm{t}-2 \text { to } \mathrm{t}-10 \\
\text { [P-value] }\end{array}$ & & & & $\begin{array}{c}3.74 \\
{[\mathrm{P}=0.022]}\end{array}$ \\
\hline $\begin{array}{l}\text { Notes: } *, * * \text { and } * * * \text { denote statistical si } \\
\text { Robust standard errors, clustered at the } \\
\text { schooling are the log of GDP per capita, } \\
\text { average years of secondary education fo } \\
\text { average years of post-secondary educat } \\
\text { Investment price and schooling are availa } \\
\text { between these points. Each of these con } \\
\text { share. }\end{array}$ & $\begin{array}{l}\text { cance at th } \\
\text { try level, } i \\
\text { price of in } \\
\text { adult ma } \\
\text { for the ad } \\
\text { nly at } 5-y \\
\text { is include }\end{array}$ & $\begin{array}{l}0 \%, 5 \% \\
\text { rackets. } \\
\text { tment re } \\
\text { ind adult } \\
\text { male at } \\
\text { intervals } \\
\text { vith as } \mathrm{n}\end{array}$ & $\begin{array}{l}\text { dd } 1 \% \text { leve } \\
\text { DP, investn } \\
\text { tive to the } \\
\text { emale popu } \\
\text { adult feme } \\
\text { d are lineal } \\
\text { y lags as } t\end{array}$ & $\begin{array}{l}\text { respectively. } \\
\text { S at price, and } \\
\text { tion, and the } \\
\text { population. } \\
\text { y interpolated } \\
\text { e top income }\end{array}$ \\
\hline
\end{tabular}




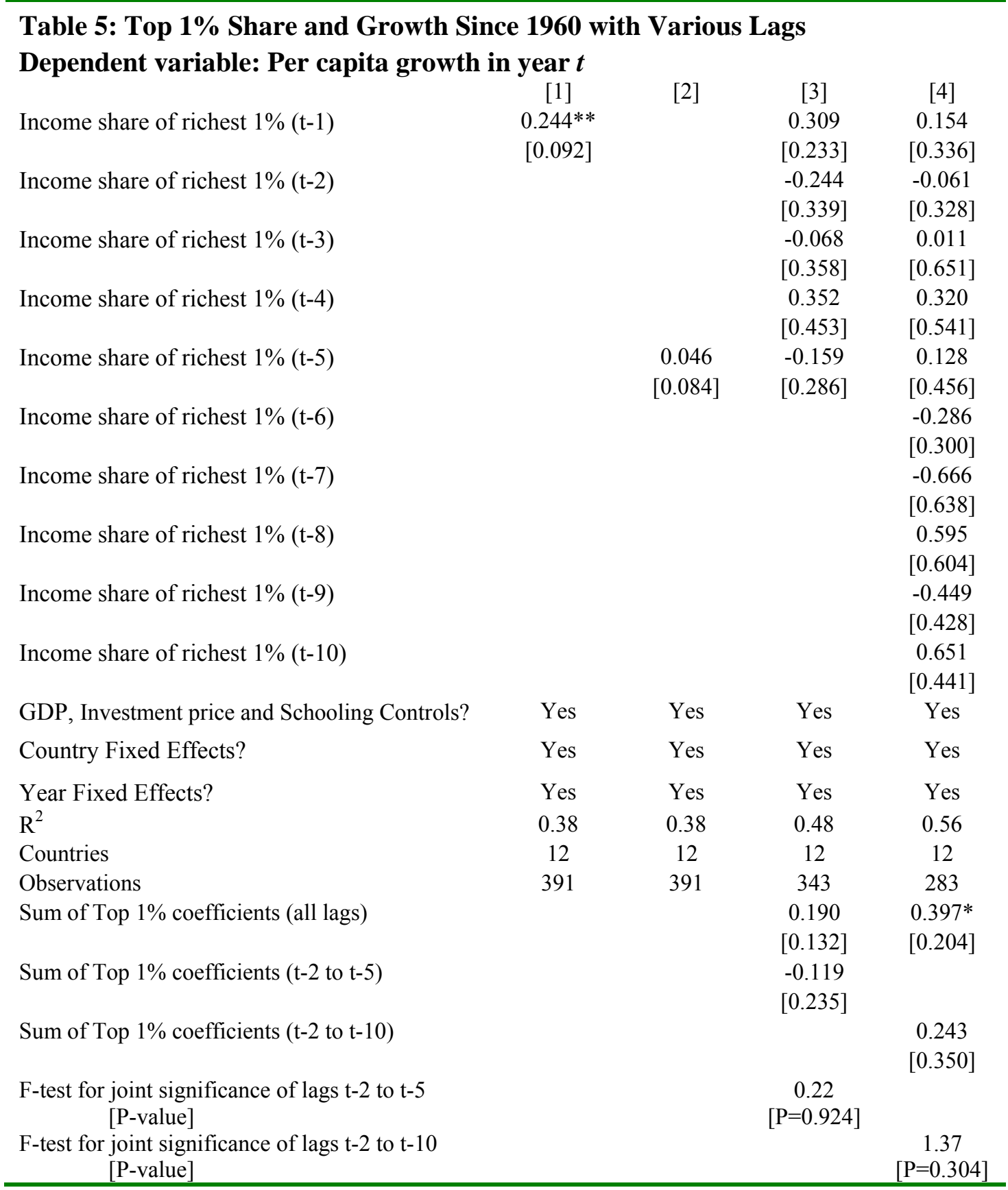

Notes: Same as Table 4. 
Table 6: Is the Relationship of Changes in Top Incomes to Growth Non-Linear?

Dependent variable: Average annual per capita growth (5 year periods)

Sample: 1960-2000

\begin{tabular}{|c|c|c|c|c|}
\hline$\Delta$ TopShare 10 & $\begin{array}{c}{[1]} \\
0.131^{* * *} \\
{[0.034]}\end{array}$ & [2] & [3] & [4] \\
\hline$\Delta$ TopShare10 $\{\Delta$ TopShare $10>0\}$ & & $\begin{array}{c}0.197 * * * \\
{[0.052]}\end{array}$ & & \\
\hline$\Delta$ TopShare $10\{\Delta$ TopShare $10 \leq 0\}$ & & $\begin{array}{c}0.053 \\
{[0.072]}\end{array}$ & & \\
\hline$\Delta$ TopShare 1 & & & $\begin{array}{l}0.192 * * \\
{[0.066]}\end{array}$ & \\
\hline$\Delta$ TopShare $1\{\Delta$ TopShare $1>0\}$ & & & & $\begin{array}{c}0.388 * * * \\
{[0.117]}\end{array}$ \\
\hline$\Delta$ TopShare $1\{\Delta$ TopShare $1 \leq 0\}$ & & & & $\begin{array}{c}-0.004 \\
{[0.174]}\end{array}$ \\
\hline Log(GDP per capita) & $\begin{array}{c}-2.215^{* *} \\
{[0.797]}\end{array}$ & $\begin{array}{c}-2.162 * * \\
{[0.820]}\end{array}$ & $\begin{array}{c}-2.399 * * \\
{[0.817]}\end{array}$ & $\begin{array}{c}-2.352 * * \\
{[0.859]}\end{array}$ \\
\hline Investment price and Schooling Controls? & Yes & Yes & Yes & Yes \\
\hline Country Fixed Effects? & No & No & No & No \\
\hline Year Fixed Effects? & Yes & Yes & Yes & Yes \\
\hline $\mathrm{R}^{2}$ & 0.44 & 0.45 & 0.43 & 0.44 \\
\hline Countries & 12 & 12 & 12 & 12 \\
\hline Observations & 85 & 85 & 85 & 85 \\
\hline F-Test. H0: $\beta($ Increase $)=\beta$ (Decrease $)$ & & $\begin{array}{l}2.055 \\
0.179\end{array}$ & & $\begin{array}{l}2.119 \\
0.173\end{array}$ \\
\hline
\end{tabular}

Notes: $*, * *$ and $* * *$ denote statistical significance at the $10 \%, 5 \%$ and $1 \%$ levels respectively. Robust standard errors, clustered at the country level, in brackets. Investment and schooling controls are the price level of investment relative to the US at PPP, the average years of high schooling for the male and female population, and the average years of post-secondary education for the male and female population. Changes in all independent variables, including inequality, are averages for six years ( $t-6$ to $t-1)$. Growth is averaged for five years ( $t$ to $t+4)$. 


\begin{tabular}{lcccc} 
Table 7: Including Shares of Top 1 per cent and Next 9 per cent Simultaneously \\
Dependent variable: \\
\multicolumn{4}{l}{ Average annual per capita growth (5 year periods) } \\
\hline & {$[1]$} & {$[2]$} & {$[3]$} & {$[4]$} \\
& Full sample & Full sample & $1960-2000$ & $1960-2000$ \\
& $(1905-2000)$ & (excl. wars) & & \\
Income share of richest 1\% & $-0.189^{* *}$ & -0.055 & 0.077 & -0.072 \\
& {$[0.078]$} & {$[0.047]$} & {$[0.077]$} & {$[0.122]$} \\
& $0.165^{*}$ & 0.130 & $0.134^{*}$ & $0.239^{* *}$ \\
Income share of next 9\% & {$[0.090]$} & {$[0.075]$} & {$[0.071]$} & {$[0.091]$} \\
& $-2.682^{* *}$ & $-3.316^{*}$ & -2.302 & -2.036 \\
Log(GDP per capita) & {$[1.069]$} & {$[1.575]$} & {$[2.923]$} & {$[2.891]$} \\
& No & No & No & Yes \\
Investment and Schooling Controls? & Yes & Yes & Yes & Yes \\
Country Fixed Effects? & Yes & Yes & Yes & Yes \\
Year Fixed Effects? & 0.32 & 0.50 & 0.49 & 0.51 \\
$\mathrm{R}^{2}$ & 12 & 12 & 12 & 12 \\
Countries & 156 & 134 & 89 & 87 \\
Observations & & &
\end{tabular}

Notes: Same as Table 3. 


\begin{tabular}{|c|c|c|c|c|}
\hline $\begin{array}{l}\text { Table 8: Inequality and C } \\
\text { Dependent variable: Ave } \\
\text { Sample is } 1960-2000\end{array}$ & $\begin{array}{l}\text { Using Gi } \\
\text { lual per }\end{array}$ & $\begin{array}{l}\text { oefficient } \\
\text { ta growth }\end{array}$ & $\begin{array}{l}1960 \\
\text { ar per }\end{array}$ & \\
\hline & {$[1]$} & [2] & [3] & [4] \\
\hline & & & & \\
\hline Gini & 0.016 & 0.021 & 0.059 & 0.087 \\
\hline & {$[0.027]$} & {$[0.027]$} & [0.040] & [0.052] \\
\hline Log(GDP per capita) & $-8.722 * * *$ & $-9.138 * * *$ & -0.668 & -0.652 \\
\hline & {$[1.608]$} & {$[1.762]$} & [4.285] & [4.491] \\
\hline $\begin{array}{l}\text { Investment price and Schooling } \\
\text { Controls? }\end{array}$ & No & Yes & No & Yes \\
\hline Country Fixed Effects? & Yes & Yes & Yes & Yes \\
\hline Year Fixed Effects? & Yes & Yes & Yes & Yes \\
\hline $\mathrm{R}^{2}$ & 0.57 & 0.57 & 0.61 & 0.64 \\
\hline Countries & 11 & 11 & 11 & 11 \\
\hline Observations & 55 & 54 & 45 & 45 \\
\hline
\end{tabular}

Notes: $*, * *$ and $* * *$ denote statistical significance at the $10 \%, 5 \%$ and $1 \%$ levels respectively. Robust standard errors, clustered at the country level, in brackets. Investment and schooling controls are the price level of investment relative to the US at PPP, the average years of high schooling for the male and female population, and the average years of post-secondary education for the male and female population. 
Table 9: Effect of Controlling for Top Tax Rates

Dependent variable: Average annual per capita growth (5 year periods)

Sample: Australia, Canada, New Zealand, United Kingdom \& United States, 19602000

\begin{tabular}{lcccc}
\hline & {$[1]$} & {$[2]$} & {$[3]$} & {$[4]$} \\
Income share of richest 10\% & $0.125^{*}$ & $0.148^{*}$ & & \\
& {$[0.045]$} & {$[0.060]$} & & \\
Income share of richest 1\% & & & 0.171 & 0.169 \\
& & & {$[0.128]$} & {$[0.141]$} \\
Log(GDP per capita) & $-7.506^{* *}$ & $-7.628^{* *}$ & $-8.233^{* *}$ & $-8.213^{* *}$ \\
& {$[1.859]$} & {$[2.135]$} & {$[2.421]$} & {$[2.670]$} \\
Top Marginal Tax Rate & & 0.010 & & -0.001 \\
& & {$[0.013]$} & & {$[0.010]$} \\
Investment and Schooling Controls? & Yes & Yes & Yes & Yes \\
Country Fixed Effects? & Yes & Yes & Yes & Yes \\
Year Fixed Effects? & Yes & Yes & Yes & Yes \\
$\mathrm{R}^{2}$ & 0.71 & 0.71 & 0.68 & 0.68 \\
Countries & 5 & 5 & 5 & 5 \\
Observations & 40 & 40 & 40 & 40 \\
\hline
\end{tabular}

Notes: $*, * *$ and $* * *$ denote statistical significance at the $10 \%, 5 \%$ and $1 \%$ levels

respectively. Robust standard errors, clustered at the country level, in brackets.

Investment and schooling controls are the price level of investment relative to the US at PPP, the average years of secondary schooling for the male and female population, and the average years of post-secondary education for the male and female population. 


\begin{tabular}{|c|c|c|c|}
\hline \multicolumn{4}{|c|}{ Table A1: Data Coverage and Adjustments } \\
\hline Country & $\mathbf{N}$ & Period(s) & Adjustments \\
\hline Australia & 61 & $1942-2002$ & Converted to calendar year basis. \\
\hline Canada & 60 & $1941-2000$ & No adjustments made. \\
\hline France & 81 & $\begin{array}{c}1905 \text { and } \\
1919-1998\end{array}$ & $\begin{array}{l}\text { Top income shares for } 1900-1910 \text { are based on average } \\
\text { data for the period, so this number is assigned to } 1905 \text {. }\end{array}$ \\
\hline Germany & 38 & $1961-1998$ & No adjustments made. \\
\hline Ireland & 30 & $\begin{array}{l}1939-1943 \\
\text { and } 1976- \\
2000\end{array}$ & Converted to calendar year basis. \\
\hline Netherlands & 86 & 1914-1999 & No adjustments made. \\
\hline New Zealand & 78 & $1925-2002$ & $\begin{array}{l}\text { Adjusted } 1 \% \text { series taken from Table } 3 \text {. Unadjusted } 10 \% \\
\text { series taken from Table } 1 \text { and adjusted in a similar manner } \\
\text { ( } 1924-40 \text { data scaled up by } 1.04 \text {, missing years } \\
\text { interpolated, and } 1924-52 \text { increased by 5.79). Both series } \\
\text { then converted to calendar year basis. }\end{array}$ \\
\hline Spain & 22 & 1981-2002 & No adjustments made \\
\hline Sweden & 87 & $\begin{array}{l}1903-1920, \\
1930-1935 \\
\text { and } 1941- \\
2003\end{array}$ & No adjustments made. \\
\hline Switzerland & 64 & 1933-1996 & $\begin{array}{l}\text { Taxpayers are only required to file returns every two } \\
\text { years, so we assign the same figure to both years (except } \\
\text { 1933). }\end{array}$ \\
\hline United Kingdom & 52 & $\begin{array}{c}1919 \text { and } \\
1950-2000\end{array}$ & $\begin{array}{l}\text { In } 1908-1989,10 \text { per cent share multiplied by } 1.081 \text { and } 1 \\
\text { per cent share multiplied by } 1.130 \text {, to take account of the } \\
\text { shift from joint to individual filing in } 1990 \text {. Converted to } \\
\text { calendar year basis. }\end{array}$ \\
\hline United States & 85 & $1917-2001$ & No adjustments made. \\
\hline Total & 744 & $1903-2003$ & \\
\hline
\end{tabular}

Note: Sample size refers to the top $10 \%$ series but is similar for the top $1 \%$ series. All adjustments are described in further detail in Leigh (2007). 


\section{Endnotes}

${ }^{1}$ A more recent database is the UNU-WIDER World Income Inequality Database, which is effectively an expanded version of the Deininger-Squire database. Similar issues apply to the use of this database as to the Deininger-Squire database.

${ }^{2}$ Piketty and Saez (2006a) identify the relationship between top income shares and growth as an important open question in the literature.

${ }^{3}$ In a paper drafted contemporaneously with this one, Roine, Vlachos and Waldenström (2007) analyze the correlates of top income shares in a panel of 16 developed and developing countries. In a first-differenced specification, they find a positive relationship between economic growth and changes in top income shares. However, an important difference between their paper and ours is that their analysis looks at contemporaneous effects, which allows causation to run in either direction; while we look only at the effect of lagged inequality on growth.

${ }^{4}$ For a more detailed treatment of the theory on inequality and growth, see Galor and Zeira (1993), Aghion, Caroli, and García-Peñalosa (1999), and Bénabou (2005).

${ }^{5}$ On tournament theory, see Lazear and Rosen (1981), Main, O’Reilly and Wade (1993); Eriksson (1999); Heyman (2005); though cf. Akerlof and Yellen (1990).

6 For instance, if credit constraints are binding, poor households may under-invest in their children's nutrition, health, and education, even when the rate of return would be high. Underinvestment is likely to be more important in poorer countries, but it probably plays some role even in the rich countries we study. Even if this is the case, however, we 
would expect under-investment in children's nutrition, health, and education in our sample to depend more on income inequality within the bottom nine income deciles than on the share of total income going to the top decile. Corruption is greater in more unequal societies (Glaeser, Scheinkman and Shleifer 2003), and higher corruption is linked to lower growth (Mauro 1995). Likewise, violent crime appears to be greater in more unequal societies (Fajnzylber, Lederman, and Loayza 2002), and high levels of crime can discourage transactions that would otherwise make both parties better off.

${ }^{7}$ For example, if countries with above-average growth in the 1950 s also had aboveaverage growth in the $1960 \mathrm{~s}$, and if above-average growth in the $1950 \mathrm{~s}$ broadened political support for efforts to reduce inequality, the cross-country association between lower inequality in 1960 and higher subsequent growth might just reflect the inequalityreducing effect of pre-1960 growth.

${ }^{8}$ Barro measured growth over a ten year window and generally measured inequality five years before the window opened. So for the first period, growth is calculated for 19651975 and is matched to a Gini coefficient from about 1960. Forbes measured growth over a five year period and generally measured inequality one year before the window opened. Thus growth from 1976 to 1980 it is matched to a Gini for 1975.

${ }^{9}$ Recall that in Alesina and Rodrik (1994) the window for the growth calculation is 19601985 and inequality is measured around 1960, so the first year of the growth window is typically concurrent with the inequality measure.

${ }^{10}$ Leigh (2007) provides data for 13 countries. In this paper we exclude Japan because information on the income share of the top $10 \%$ is unavailable. 
${ }^{11}$ In Australia, Canada and Spain, the tax unit is the individual. In France, Ireland, the Netherlands, Switzerland and the United States, the tax unit is a married couple or single individuals. Germany has a hybrid system, with most taxpayers filing as tax units, and the very rich filing as individuals. The tax unit switched from the household to the individual in New Zealand (in 1953), Sweden (in 1971) and in the United Kingdom (in 1990). See Leigh (2007) for details on the adjustments made to the top incomes series in these countries to account for this shift.

12 The available data on tax underreporting are patchy, but Leigh (2009) finds no evidence of large differences across countries, nor of changes over time within countries for which multiple measures of tax underreporting are available.

${ }^{13}$ According to the Deininger-Squire database, more than half of this decline in the Gini coefficient -8 points - took place between 1975 and 1979 . Apparently occurring in just four years, this change is almost twice as large as the rise in the United States Gini coefficient over the $1980 \mathrm{~s}$ - a period when inequality is generally regarded to have risen dramatically (Card and Di Nardo 2002). Another possible interpretation is that the difference was due to a change in the underlying data source. The Deininger-Squire "accept series" is taken from a United Nations compendium of income distribution statistics for the years 1956-75, and from the Luxembourg Income Study from 1979 onwards.

14 We use GDP per capita data from Maddison (2003, 2007), expressed in 1990 International Geary-Khamis dollars. We use Maddison's estimates because they cover the complete period, while most other data sources are limited to the post-1945 era. As we 
show below, our results for the period from 1960 onwards do not change if we use GDP growth or GNI growth from the World Development Indicators database.

${ }^{15}$ In Monte Carlo simulations using 21 years of data from the US Current Population Survey, Bertrand et al. (2004) find that this technique performs quite well in finite samples. The rejection rate (at the 5 per cent level) is 6.3 per cent for $\mathrm{N}=50 ; 5.8$ per cent for $\mathrm{N}=20$; and 8 per cent for $\mathrm{N}=10 . \mathrm{N}=12$ in our sample.

${ }^{16}$ The price level of investment (PPPI) is a proxy for price distortions in the economy. It is calculated by dividing the purchasing power parity (PPP) for investment goods by the US dollar exchange rate. As countries become richer, the relative price of investment goods tends to fall (Summers and Heston 1991). By construction, PPPI for the US takes the value of unity in all years.

${ }^{17}$ Regarding the practice of using 5 or 10 year windows to measure growth, Barro (2000: 11) notes: "The low-frequency context accords, in any event, with the underlying theories of growth, which do not attempt to explain short-run business fluctuations. In these theories, the short-run response-for example, of the rate of economic growth to a change in a public institution-is not as clearly specified as the medium- and long-run response. Therefore, the application of the theories to annual or other high-frequency observations would compound the measurement error in the data by emphasizing errors related to the timing of relationships."

${ }^{18} \mathrm{We}$ also estimated this parameter by regressing average annual growth between $t$ and $t+4$ on the mean of TopShare 10 from $t-1$ to $t+3$, making the mean lag one year $\operatorname{In}$ this specification the coefficient on the mean of TopShare10 was $0.130(\mathrm{se}=0.0303)$. This 
estimate, like the 0.121 estimate in the text, may incorporate some reverse causation, because growth in earlier parts of the 5-year window can influence inequality later in the window.

${ }^{19}$ We also experimented with interacting our top income share measures with the change in top income shares from one five-year period to the next (i.e. augmenting the specification in column 6 of Table 3 by adding a difference and a difference interaction). When we do this, the coefficient on the top income share variables remain similar, and both the difference variable and the interaction are statistically insignificant.

${ }^{20}$ Taken at face value our point estimates imply that increases in inequality raise growth while decreases in inequality have little effect on growth. If that were really the case, regularly raising and lowering top income shares would allow countries to raise growth while leaving top income shares unchanged over the long run. Because this implication of our point estimates strikes us as implausible, we emphasize the size of the standard errors.

${ }^{21}$ The correlation between the shares of the top 1 per cent and the next 9 per cent in the 1960-2000 sample is 0.4 ; this correlation rises to 0.6 in the post-1980 period.

${ }^{22}$ The income concept in the Luxembourg Income Study is household disposable income, equivalized by dividing by the square root of the number of household members.

${ }^{23}$ Where $\beta$ is the coefficient estimate, $\mathrm{I}$ is the increase in inequality, and $\mathrm{N}$ is the number of years over which the effect is cumulated, the proportional increase in GDP is $\exp (\beta \times I \times N)-1$. Since we are dealing with relatively small values of $\beta$, I, and $N$, it makes little difference if we simplify this using the approximation $\beta \times \mathrm{I} \times \mathrm{N}$. 
${ }^{24}$ If $t$ is the number of years over which a rise in TopShare 10 must be sustained for the bottom nine deciles to gain enough in absolute terms to offset the decline in their share of personal income, and if the one point increase in TopShare10 continues to raise the log of per capita GDP by 0.121 , "breakeven" will occur when $t=[\ln (68 / 58)] / 0.0121=13.1$ years. The estimates using annual growth data and ten years of data on TopShare10 (Table 4, column 4) have qualitatively similar implications. 